\title{
Review of the species level taxonomy of the neotropical butterfly genus Oenomaus (Lycaenidae, Theclinae, Eumaeini)
}

\author{
Christophe Faynel ${ }^{1, \dagger}$, Robert C. Busby ${ }^{2, \ddagger}$, Robert K. Robbins ${ }^{3, \S}$
}

I 16 rue des Aspres, F-34160 Montaud, France 27 Countryside Way, Andover, MA 01810-6041 USA

3 Department of Entomology, PO Box 37012, NHB Stop 105, Smithsonian Institution, Washington, DC 20013-7012 USA

† urn:lsid:zoobank.org:author:38C2FC5F-7A0A-4A8B-A486-4E650745FD7D

¥ urn:lsid:zoobank.org:author:4F3EA150-C9F6-4EC7-A88C-59FD6D256B5A

§ urn:lsid:zoobank.org:author:44061674-2F12-49EE-BC5F-A264F51A3391

Corresponding author: Christophe Faynel (christophe.faynel@wanadoo.fr)

Academic editor: Carlos Peña | Received 11 May 2012 | Accepted 28 August 2012 | Published 20 September 2012

urn:lsid:zoobank.org:pub:B5F5FE01-C483-4CBE-946A-320150B85E29

Citation: Faynel C, Busby RC, Robbins RK (2012) Review of the species level taxonomy of the neotropical butterfly genus Oenomaus (Lycaenidae, Theclinae, Eumaeini). ZooKeys 222: 11-45. doi: 10.3897/zookeys.222.3375

\begin{abstract}
Seven new species of the Neotropical hairstreak genus Oenomaus are described: O. mancha Busby \& Faynel, sp. n. (type locality Ecuador); O. gwenish Robbins \& Faynel, sp. n. (type locality Panama); $O$. lea Faynel \& Robbins, sp. n. (type locality Ecuador); O. myrteana Busby, Robbins \& Faynel, sp. n. (type locality Ecuador); O. mentirosa Faynel \& Robbins, sp. n. (type locality Peru); O. andi Busby \& Faynel, sp. n. (type locality Ecuador) and O. moseri Robbins \& Faynel, sp. n. (type locality Brazil, Santa Catarina). For each new Oenomaus species, we present diagnostic characters and notes on its habitat and biology. We illustrate adults, genitalia, and distribution. New distributional and biological data are presented for 21 previously described Oenomaus species. Oenomaus melleus guyanensis Faynel, 2008 is treated as a new synonym of O.m. melleus (Druce, 1907). Females are described and associated with males for ten species using a variety of factors, including mitochondrial COI DNA "barcode" sequences. We summarize the reasons why the number of recognized Oenomaus species has grown in the past decade from one species to 28 species. Finally, we overview the habitats that Oenomaus species occupy and note that the agricultural pest on Annonaceae, O. ortygnus, is the only Oenomaus species that regularly occurs in greatly disturbed habitats.
\end{abstract}

Copyright Christophe Faynel et al. This is an open access article distributed under the terms of the Creative Commons Attribution License 3.0 (CC-BY), which permits unrestricted use, distribution, and reproduction in any medium, provided the original author and source are credited. 


\section{Résumé}

Sept nouvelles espèces appartenant au genre néotropical Oenomaus Hübner sont décrites : $O$. mancha Busby \& Faynel, sp. n. (localité type : Equateur); O. gwenish Robbins \& Faynel, sp. n. (localité type : Panama); O. lea Faynel \& Robbins, sp. n. (localité type : Equateur); O. myrteana Busby, Robbins \& Faynel, sp. n. (localité type : Equateur); O. mentirosa Faynel \& Robbins, sp. n. (localité type : Pérou); $O$. andi Busby et Faynel, sp. n. (localité type : Equateur) et $O$. moseri Robbins \& Faynel, sp. n. (localité type : Brésil, Santa Catarina). Pour chaque nouvelle espèce, les caractères diagnostiques sont présentés et sont accompagnés de remarques sur l'habitat et la biologie. Les faces dorsales et ventrales des adultes et les organes génitaux sont illustrés et des cartes de répartition sont données. Dans une deuxième partie, de nouvelles données sont présentées pour 21 espèces d'Oenomaus précédemment décrites. Oenomaus melleus guyanensis Faynel, 2008 est mis en synonymie avec O. m. melleus (Druce, 1907). Les femelles sont décrites et associées avec des mâles en utilisant plusieurs moyens, y compris les séquences d'ADN mitochondrial COI. Les raisons pour lesquelles le nombre d'espèces d'Oenomaus décrites a fortement augmenté ces dernières années sont évoquées. Finalement, une vue d'ensemble des habitats occupés par les différentes espèces d'Oenomaus est présentée. O. ortygnus, qui est un parasite agricole connu sur Annonaceae, est la seule espèce d'Oenomaus qui se trouve régulièrement dans des habitats perturbés.

\section{Keywords}

Annonaceae, Neotropics, Porthecla

\section{Introduction}

The widespread Neotropical hairstreak Oenomaus ortygnus (Cramer) is a pest of cultivated soursop (Annona muricata L.) and relatives (Annonaceae), and aspects of its biology have been documented for nearly a century (e.g., Dampf 1929; Fennah 1937; Ballou 1945; Guagliumi 1965, 1967; Araque 1967; d’Araújo e Silva et al. 1967-1968; Leal 1970; Kendall 1975; Domínguez 1978; Peña et al. 2002; Castañeda-Vildózola et al. 2011). In contrast, the taxonomy of the genus Oenomaus Hübner (Lycaenidae: Theclinae) was not addressed until recently. Oenomaus was considered to be a monotypic genus of uncertain affinity (Clench 1964) until Robbins (2004) listed 22 Neotropical species (18 undescribed). Shortly thereafter, Faynel $(2006,2008)$ and Faynel and Moser (2008) documented the substantive variation of male genitalic structures in Oenomaus and described 12 new species from male holotypes. However, associating females with the males was problematic for many of these species.

A close phylogenetic relationship between Oenomaus and Porthecla Robbins was suggested when Robbins and Duarte (2004) described the latter genus. However, the distinction between these two genera has been disputed because of different interpretations of male genitalic morphology, which has resulted in the uncertain generic placement for a few species (Faynel 2007; Faynel et al. 2011). The species level taxonomy of Porthecla has been treated (Faynel et al. 2011), but a similar overview for Oenomaus is lacking.

We present new species level taxonomic information for Oenomaus in this paper. We describe seven new Oenomaus species. Next, we update information on the distribution, habitat, variation, and biology of the 21 species that were previously described 
in or transferred to Oenomaus (Robbins 2004; Faynel 2007; Faynel et al. 2011). We also associate females with males for many species based on male-female pairs collected in copula or on similarity of ventral wing patterns, geographic distribution, and DNA 'barcode' sequences (the mitochondrial COI gene). The morphology of newly associated females is detailed. With the species level taxonomy of Porthecla recently reviewed (Faynel et al. 2011), the goal of this paper is do the same kind of review for Oenomaus. This information will serve as the foundation for a phylogenetic analysis of Oenomaus and Porthecla.

\section{Materials and methods}

Genitalic terms follow those in Klots (1970), as modified for the Eumaeini in Robbins (1991). Wing veins are named following Comstock (1918), and wing cells are named by the veins that border them. Otherwise, morphological terms follow Snodgrass (1935). Abbreviations used repeatedly in the text are FW: forewing, HW: hindwing, D: dorsal, V: ventral and SD: standard deviation. Brazilian states are noted by their standard two letter abbreviations.

Illustrated adults of Oenomaus are noted in the material examined sections, and each genitalia drawing is of the adult illustrated. The structure of the male genitalia valvae in Oenomaus is complex, for which reason we present them in ventral, lateral, and dorsal views.

Biogeographical zones follow Brown (1982), who partitioned the forested continental Neotropics into the Transandean Region, Andean Region, Amazon Region, and Atlantic Region. Larval food plant nomenclature follows the Tropicos database of the Missouri Botanical Garden (http://www.Tropicos.org, accessed April 2012). Following Holdridge (1967), we classify lowland forests as humid/wet (> $200 \mathrm{~cm}$ annual precipitation) or dry/deciduous (100-200 cm annual precipitation). Many eumaeines display male territorial behavior on hilltops (Nicolay 1971; Alcock and O'Neill 1987; Prieto and Dahners 2006, 2009; Robbins et al. 2012). Males wait on hilltops for receptive females to fly through the territory and "defend" these areas by flying at other males that enter the territory. Recorded times from our fieldwork for hilltopping behavior are the standard time at that locality. Finally, traps baited with decaying fish attract some lycaenid species and not others. We note the gender for each species which has been collected using fish-baited traps.

The ventral wing pattern in Oenomaus is sexually monomorphic, so associating the sexes of species with distinct ventral wing patterns, such as O. ortygnus, is straightforward. However, a majority of Oenomaus species have a ventral wing pattern that is similar to that of $O$. atena (Hewitson). Among these, some can be associated because they have distinct ventral wing pattern elements, such as those of $O$. isabellae (Faynel 2008), or because a mating pair was collected in copula. In other cases, we associate females with males if at least three of the following four criteria are met: (1) females have a ventral wing pattern that is indistinguishable from that of males, (2) females have a geo- 
graphic distribution that is similar to that of males, (3) both sexes are found in a locality where other species with the same wing pattern are unrecorded, and (4) divergence of DNA "barcode" sequences between the sexes is less than $2 \%$ (see next paragraph).

The mitochondrial COI gene sequence (commonly called a DNA "barcode") has been useful, when combined with other characters, in distinguishing lepidopteran species in a single area (e.g., Hebert et al. 2004; Hajibabaei et al. 2006; Janzen et al. 2009). Because genitalic and wing pattern characters generally provide clear species boundaries in Oenomaus, our purpose in determining COI gene sequences was to aid in associating females with males, as noted.

We use the following acronyms for collections, following those for public institutions listed on the website hbs.bishopmuseum.org/codens/codens-inst.html (accessed April 2012):

AMNH American Museum of Natural History, New York, New York, USA.

ANSP Academy of Natural Sciences, Philadelphia, Pennsylvania, USA.

CF Private collection of Christophe Faynel, France.

CMNH Carnegie Museum of Natural History, Pittsburgh, Pennsylvania, USA.

DZUP Universidade Federal do Paraná, Curitiba, Paraná, Brazil.

FSMC Florida Museum of Natural History, Allyn Museum, University of Florida, Gainesville, Florida, USA.

JFLC Private collection of Jean François Le Crom, Bogotá, Colombia.

LYD Private collection of Louis and Yvan Diringer, France.

MC Private collection of Alfred Moser, São Leopoldo, Rio Grande do Sul, Brazil.

MNHN Muséum national d'Histoire naturelle, Paris, France.

MUSM Museo de Historia Natural, Universidad Nacional Mayor de San Marcos, Lima, Perú.

OSAC Oregon State University Corvallis, Oregon, USA.

PB Private collection of Pierre Boyer, Le Puy Sainte Réparade, France.

RCB Private collection of Robert C. Busby, Andover, Massachusetts, USA.

SMF Forschungsinstitut und Naturmuseum Senckenberg, Frankfurt-am-Main, Germany.

USNM Smithsonian Institution, Washington, DC USA.

\section{New species}

A distinguishing trait of Oenomaus and Porthecla among members of the Panthiades Section of the Eumaeini is the lack of an orange cubital spot (Robbins and Duarte 2004, Faynel et al. 2011). Of the seven new species described in this paper, six lack the spot while some specimens of the seventh species may have a vestigial remnant composed of a few orange scales (Figs 1-11). Oenomaus and Porthecla are distinguished from each other by shape of the valvae in lateral aspect, but interpretation of this morphology has varied for some species (Robbins and Duarte 2004, Faynel 2007, Faynel 
et al. 2011). However, six of the newly described species have non-triangular, bifurcate valvae in lateral aspect (Figs 20-25), which is characteristic of Oenomaus. The seventh species is known only from a female, but the similarities in its wing pattern (Figs 2-3) and genitalia (Figs 28-29) to two other Oenomaus species support its generic placement. For these reasons, the following new species are described in Oenomaus.

\section{Oenomaus mancha Busby \& Faynel, sp. n.}

urn:lsid:zoobank.org:act:4DF6102F-0A25-46B8-8F56-6E33D791A5F2 http://species-id.net/wiki/Oenomaus_mancha

Figs 1, 2, 20, 26, 38, 46

Type-locality. Ecuador: Sucumbíos, 5 km Puerto Libre-La Bonita Road, $0^{\circ} 13.0^{\prime} \mathrm{N}$, $77^{\circ} 29.3^{\prime} \mathrm{W}, 700 \mathrm{~m}$. The road going west from Puerto Libre increases in elevation as the terrain becomes hillier. The collecting spot was in wet forest and was easily accessed by a muddy logging trail. Since 2005, logging has continued, leaving very few tall trees in the once beautiful forest.

Type-specimen. Holotype $\widehat{\delta}$ (Fig. 1) labeled as "ECUADOR: Sucumbios / 5 km Puerto Libre-La Bonita Road / 0 $13.0^{\prime} \mathrm{N}, 77^{\circ} 29.3^{\prime} \mathrm{W}, 700$ m / 23 February 2005 / Robert C. Busby, leg." [rectangular, white, printed], "11:00 hrs / 5 m” [rectangular, white, handwritten, blue ink], "GENITALIA No. / 2011: 419 / C. FAYNEL" [rectangular, green, printed] "Holotype $\widehat{\overbrace{}}$ / Oenomaus mancha / Busby \& Faynel, 2012" [rectangular, red, printed]. Deposited in USNM.

Paratypes: Ecuador. $2{ }^{\top}$ : Napo, $14 \mathrm{~km}$ Tena-Puyo Road, $1^{\circ} 06.7^{\prime} \mathrm{S}, 77^{\circ} 46.9^{\prime} \mathrm{W}$, 600 m, 24.IX.2011, (Apuya) Robert C. Busby leg. (RCB); Napo, Pimpilala, [ GPS data : $1^{\circ} 04.6 \mathrm{~S}, 77^{\circ} 56.2^{\prime} \mathrm{W}$ ], 600-700 m, Euclides Aldaz leg., XII.2003, gen. prep.

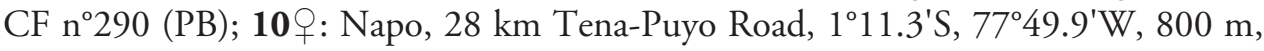
VIII.2006 (El Capricho) I. Aldas \& R. C. Busby leg. (RCB); Napo, 12 km Tena-Puyo Road, 105.3'S, 7747.4' W, 600 m, 28.VIII.2009, (Finca San Carlo) D. H. Ahrenholz, R. C. Busby, leg. (RCB); Napo, 14 km Tena-Puyo Road, $1^{\circ} 06.7^{\prime} \mathrm{S}, 77^{\circ} 46.9^{\prime} \mathrm{W}$ 600 m, VIII.2005, (Apuya) I. Aldas \& R. C. Busby leg. (RCB) ; Napo, 14 km TenaPuyo Road, $1^{\circ} 06.7^{\prime} \mathrm{S}, 77^{\circ} 46.9^{\prime} \mathrm{W}, 600 \mathrm{~m}, 17 . \mathrm{X} .2010$, (Apuya) I. Aldas \& R. C. Busby leg. (RCB); Napo, 14 km Tena-Puyo Road, $1^{\circ} 06.7^{\prime} \mathrm{S}, 77^{\circ} 46.9^{\prime} \mathrm{W}, 600 \mathrm{~m}, 22 . X .2010$, (Apuya) I. Aldas \& R. C. Busby leg. (RCB); Pastaza Province, $32 \mathrm{~km} \mathrm{S.} \mathrm{of} \mathrm{Puyo,}$ 1000 m, 21-23.X.1995 Robert C. Busby leg. (RCB); Pastaza Province, 45 km PuyoArajuno Rd, 1000 m, 15.IX.1999, Robert C. Busby leg., gen. prep. CF nº20 (RCB); Pastaza Province, 45 km Puyo-Arajuno Rd, 1000 m, 26.IX.1999, Robert C. Busby leg., gen. prep. CF n ${ }^{\circ} 421$ (RCB); Pastaza Province, 45 km Puyo-Arajuno Rd, 1000 m, 26.IX.1999, Robert C. Busby leg. (RCB); Pastaza, Puyo, 1000 m, 14.X.1989, D.H. Ahrenholz leg., gen. prep. CF nº 407 (USNM ENT 00180037) (Fig. 2).

Description, diagnosis and recognition as a distinct species. Male FW length: $20.8 \mathrm{~mm}(\mathrm{SD}=1.9, N=2)$. Female FW length: $19.4 \mathrm{~mm}(\mathrm{SD}=0.5, N=3)$. Wing pattern (Figs 1,2) and genitalia (Figs 20, 26) illustrated. Oenomaus mancha, O. ortyg- 

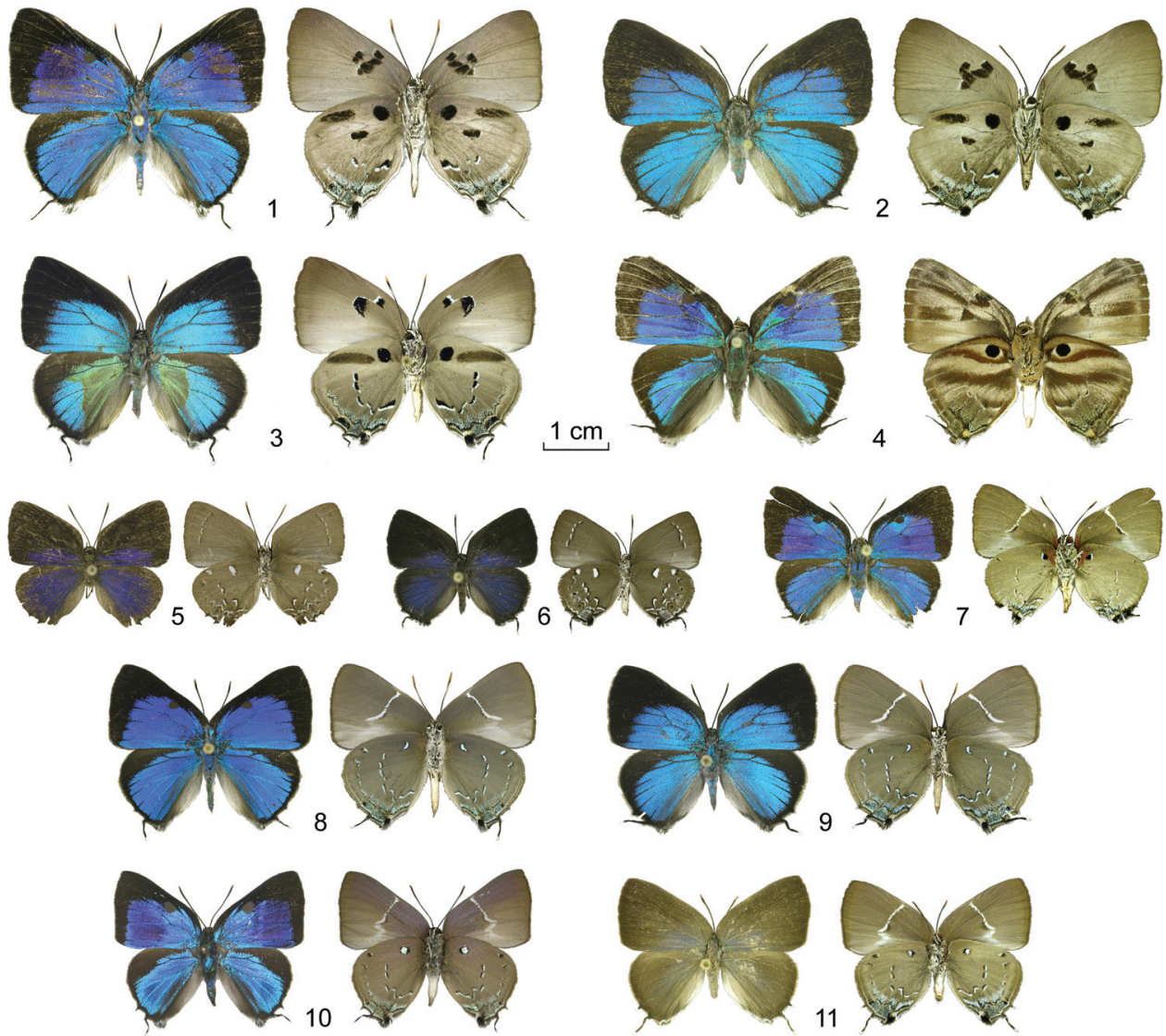

Figures I-II. Oenomaus, new species: adults (dorsal surface at left, ventral surface at right). I $\delta \quad 0$. mancha (holotype, Ecuador) 2 + O. mancha (paratype, Ecuador) 3 \& O. gwenish (holotype, Panama) 4 ก O. lea (holotype, Peru) 5 O O. myrteana (holotype, Ecuador) 6 O O. myrteana (paratype, Ecuador)

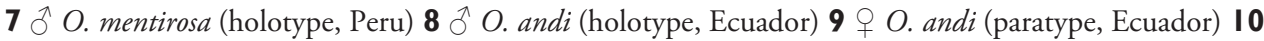
ô O. moseri (holotype, Brazil) II \& O. moseri (paratype, Brazil).

nus, and O. gwenish (named below) share a unique ventral wing pattern in which the VFW postmedian line (displaced basally, but by tradition still called the postmedian line) is composed of "disjointed" large black spots on a gray ground color (Fig. 3 for O. gwenish and Figs 2, 4 for O. ortygnus in Faynel 2006). Oenomaus mancha differs from O. ortygnus by (1) a black patch in the distal part of the VHW cell Sc+R1-Rs, elongated basally, (2) no black mark in VFW cell Costa-Sc, and (3) a black band crossing the VFW discal cell. In addition, females of $O$. mancha are a brighter blue dorsally, while the blue on the DFW of males is somewhat less expansive with the scent pad not completely encircled by blue scales as in $O$. ortygnus. Male and female genitalia of O. mancha and O. ortygnus also differ (Figs 25, 28 for O. ortygnus in Faynel 2006). In particular, the dorsal part of the valvae of the male genitalia in lateral aspect is shorter and has a more sharply tapered posterior end in ventral view. In the female, the bifid 
posterior end of the lamella postvaginalis is less marked and the anterior end of the ductus bursae is curved more sharply. One paratype from Ecuador has been barcoded (CF-LYC-190), and its sequence is 3.5\% divergent from the sequences of two males of O. ortygnus (CF-LYC-147 from Peru and CF-LYC-146 from Mexico, see Table 1) while the two $O$. ortygnus sequences differ by only $1.5 \%$. Oenomaus ortygnus and $O$. mancha are sympatric in eastern Ecuador in Napo Province at approximately $450 \mathrm{~m}$.

Etymology. The name of this species is derived from the Spanish word "mancha", which means spot, referring to the very distinctive, elongated black spot in VHW cell $\mathrm{Sc}+\mathrm{R} 1-\mathrm{Rs}$. The name is a feminine noun in apposition.

Habitat and distribution. Oenomaus mancha occurs widely in wet forest in eastern Ecuador at elevations ranging from 400 to $1100 \mathrm{~m}$ (Fig. 46). Although it is sympatric with $O$. ortygnus in wet forest, it does not occur in the highly disturbed habitats in which $O$. ortygnus sometimes occurs. It is yet an open question whether $O$. mancha is a lowland or lower montane species.

Behavior. The holotype male was landed on a leaf about $5 \mathrm{~m}$ above the ground at 11:00 hours. Males and females are attracted to traps baited with rotting fish (vouchers in $\mathrm{RCB}$ ).

Table I. Comparison of inter- and intraspecific divergences (in \% rounded to the nearest tenth) for the DNA "barcodes" of 19 Oenomaus male species obtained with BOLD (noted as -- when not available). Number of males examined in brackets.

\begin{tabular}{|c|c|c|c|c|c|c|c|c|c|c|c|c|c|c|c|c|c|c|c|}
\hline & 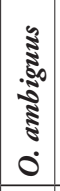 & $\begin{array}{c}3 \\
5 \\
0 \\
0 \\
0 \\
0\end{array}$ & 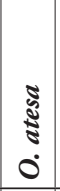 & 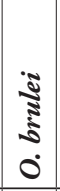 & 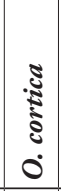 & 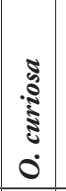 & $\mid \begin{array}{c}0 \\
0 \\
0 \\
0 \\
0 \\
0 \\
0 \\
5 \\
0\end{array}$ & $\begin{array}{c}-3 \\
0 \\
0 \\
0\end{array}$ & 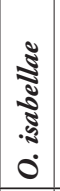 & 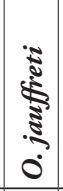 & $\begin{array}{l}\Xi \\
0 \\
0\end{array}$ & \begin{tabular}{c}
3 \\
\multirow{3}{3}{} \\
3 \\
$\vdots$ \\
0 \\
0
\end{tabular} & 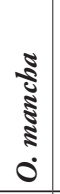 & 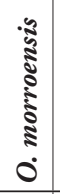 & 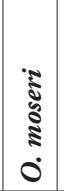 & 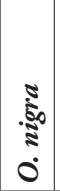 & 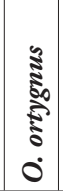 & $\mid$ & 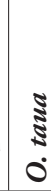 \\
\hline O. ambiguus (3) & 0.2 & & & & & & & & & & & & & & & & & & \\
\hline O. atena (1) & 6.9 & -- & & & & & & & & & & & & & & & & & \\
\hline O. atesa (1) & 7.2 & 7.0 & -- & & & & & & & & & & & & & & & & \\
\hline O. brulei (2) & 6.2 & 6.2 & 7.4 & 0.3 & & & & & & & & & & & & & & & \\
\hline O. cortica (3) & 2.8 & 5.5 & 7.5 & 5.9 & 0.5 & & & & & & & & & & & & & & \\
\hline O. curiosa (4) & 7.9 & 6.5 & 5.3 & 6.9 & 7.4 & 0.6 & & & & & & & & & & & & & \\
\hline O. cyanovenata (4) & 7.1 & 5.4 & 7.2 & 7.3 & 5.8 & 6.4 & 0 & & & & & & & & & & & & \\
\hline O. gaia (3) & 2.4 & 5.3 & 7.0 & 5.6 & 1.0 & 7.2 & 5.9 & 0.7 & & & & & & & & & & & \\
\hline O. isabellae (1) & 6.2 & 6.7 & 7.6 & 7.3 & 5.8 & 7.9 & 6.1 & 5.6 & -- & & & & & & & & & & \\
\hline O. jauffreti (4) & 7.0 & 6.5 & 7.0 & 6.2 & 6.4 & 7.6 & 6.9 & 6.1 & 4.9 & 1.6 & & & & & & & & & \\
\hline O. lea (1) & 6.9 & 4.7 & 6.7 & 6.3 & 6.1 & 6.2 & 5.9 & 5.9 & 7.3 & 5.8 & -- & & & & & & & & \\
\hline O. magnus (1) & 7.9 & 6.9 & 7.6 & 7.6 & 7.0 & 7.5 & 6.9 & 6.8 & 4.5 & 5.9 & 7.7 & -- & & & & & & & \\
\hline O. mancha (1) & 5.2 & 5.2 & 5.7 & 5.7 & 4.9 & 5.9 & 5.6 & 4.3 & 4.9 & 5.4 & $5.6 \mathrm{C}$ & 6.4 & -- & & & & & & \\
\hline O. morroensis (1) & 2.3 & 4.8 & 7.1 & 4.8 & 0.9 & 7.1 & 5.4 & 0.9 & 5.7 & 6.3 & $5.7 \mathrm{C}$ & 6.8 & 5 & -- & & & & & \\
\hline O. moseri (2) & 5.7 & 5.9 & 6.7 & 6.9 & 5.7 & 6.9 & 4.0 & 5.2 & 5.6 & 5.8 & $5.8 \mathrm{C}$ & 6.64 & 4.9 & 5.1 & 0 & & & & \\
\hline O. nigra (1) & 7.7 & 6.7 & 5.7 & 8.4 & 7.8 & 5.9 & 7.6 & 7.2 & 7.8 & 6.9 & \begin{tabular}{|l|l}
5.97 \\
\end{tabular} & 7.26 & 6.4 & 7.7 & 7 & -- & & & \\
\hline O. ortygnus (2) & 6.7 & 5.7 & 6.6 & 7.1 & 6.3 & 6.4 & 6.3 & 6.1 & 6.3 & 6.3 & $6.3 c$ & 6.23 & 3.5 & 6.2 & 5.4 & 6.6 & 1.5 & & \\
\hline O. poirieri (1) & 7.7 & 6.9 & 7.5 & 7.2 & 7.5 & 8.0 & 6.6 & 7.0 & 5.2 & 4.6 & $7.5 \mathrm{C}$ & $6.2 \mathrm{C}$ & 6.1 & 6.9 & 5.3 & 7.6 & 6.2 & -- & \\
\hline O. taua (2) & 5.9 & 5.2 & 5.4 & 6.1 & 5.3 & 6.0 & 5.1 & 4.9 & 5.2 & 4.7 & \begin{tabular}{|l|l|l}
4.3 & 5 \\
\end{tabular} & \begin{tabular}{|l|l|}
5.9 & 4 \\
\end{tabular} & 4.1 & 5.4 & 4.8 & 6.1 & 4.9 & 5.6 & 0 \\
\hline
\end{tabular}


Table 2. Species of Oenomaus sampled with BOLD (project NLYCA), with sample identifications, localities and GenBank accession numbers.

\begin{tabular}{|c|c|c|c|}
\hline Species & Sample ID & Locality & GenBank Accession Numbers \\
\hline O. ambiguus Faynel, 2008 & CF-LYC-025 & Peru & HQ966548 \\
\hline O. ambiguus Faynel, 2008 & CF-LYC-183 & Peru & JX458731 \\
\hline O. ambiguus Faynel, 2008 & CF-LYC-189 & Peru & JX458734 \\
\hline O. atena (Hewitson, 1867) & CF-LYC-084 & Peru & HQ966592 \\
\hline O. atesa (Hewitson, 1867) & CF-LYC-003 & French Guiana & HQ966543 \\
\hline O. brulei Faynel, 2008 & CF-LYC-033 & French Guiana & HQ966552 \\
\hline O. brulei Faynel, 2008 & CF-LYC-035 & French Guiana & HQ966554 \\
\hline O. cortica (D'Abrera, 1995) & CF-LYC-051 & Brazil & HQ966565 \\
\hline O. cortica (D'Abrera, 1995) & CF-LYC-052 & Brazil & HQ966566 \\
\hline O. cortica (D'Abrera, 1995) & CF-LYC-188 & Peru & JX458722 \\
\hline O. curiosa Faynel \& Moser, 2008 & CF-LYC-036 & French Guiana & HQ966555 \\
\hline O. curiosa Faynel \& Moser, 2008 & CF-LYC-037 & French Guiana & HQ966556 \\
\hline O. curiosa Faynel \& Moser, 2008 & CF-LYC-016 & Peru & JX458726 \\
\hline O. curiosa Faynel \& Moser, 2008 & CF-LYC-184 & Peru & JX458730 \\
\hline O. cyanovenata (D'Abrera, 1995) & CF-LYC-049 & Brazil & HQ966564 \\
\hline O. cyanovenata (D'Abrera, 1995) & CF-LYC-048 & Brazil & HQ966563 \\
\hline O. cyanovenata (D'Abrera, 1995) & CF-LYC-047 & French Guiana & JX458737 \\
\hline O. cyanovenata (D'Abrera, 1995) & CF-LYC-182 & Peru & JX458728 \\
\hline O. gaia Faynel, 2008 & CF-LYC-024 & Peru & JX458720 \\
\hline O. gaia Faynel, 2008 & CF-LYC-023 & French Guiana & JX458719 \\
\hline O. gaia Faynel, 2008 & CF-LYC-187 & Peru & JX458721 \\
\hline O. isabellae Faynel, 2006 & CF-LYC-006 & Brazil & HQ966545 \\
\hline O. jauffreti Faynel \& Moser, 2008 & CF-LYC-030 & Brazil & JX458724 \\
\hline O. jauffreti Faynel \& Moser, 2008 & CF-LYC-029 & French Guiana & HQ966549 \\
\hline O. jauffreti Faynel \& Moser, 2008 & CF-LYC-028 & Brazil & JX458727 \\
\hline O. jauffreti Faynel \& Moser, 2008 & CF-LYC-186 & Peru & JX458732 \\
\hline O. lea Faynel \& Robbins, 2012 & CF-LYC-005 & Peru & HQ966544 \\
\hline O. magnus Faynel \& Moser, 2008 & CF-LYC-020 & Peru & HQ966547 \\
\hline O. mancha Busby \& Faynel, 2012 & CF-LYC-190 & Ecuador & JX458723 \\
\hline O. morroensis Faynel \& Moser, 2008 & CF-LYC-015 & Brazil & JX458736 \\
\hline O. moseri Robbins \& Faynel, 2012 & CF-LYC-012 & Brazil & JX458735 \\
\hline O. moseri Robbins \& Faynel, 2012 & CF-LYC-063 & Brazil & HQ966576 \\
\hline O. nigra Faynel \& Moser, 2008 & CF-LYC-148 & Peru & JX458729 \\
\hline O. ortygnus (Cramer, 1779) & CF-LYC-146 & Mexico & JX458738 \\
\hline O. ortygnus (Cramer, 1779) & CF-LYC-147 & Peru & JX458733 \\
\hline O. poirieri Faynel, 2008 & CF-LYC-011 & French Guiana & JX458725 \\
\hline O. taua Faynel \& Moser, 2008 & CF-LYC-085 & Peru & HQ966593 \\
\hline O. taua Faynel \& Moser, 2008 & CF-LYC-185 & Peru & JX458739 \\
\hline
\end{tabular}


Oenomaus gwenish Robbins \& Faynel, sp. n. urn:lsid:zoobank.org:act:D35807B0-C3C3-4384-BB59-E294B3E06F97 http://species-id.net/wiki/Oenomaus_gwenish Figs 3, 27, 46

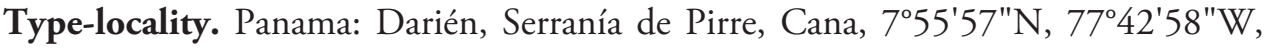
$1000 \mathrm{~m}$. Serranía de Pirre at $1000 \mathrm{~m}$ was uncut wet lower montane forest in 1984. The only disturbance was a defunct gold mine camp and associated dirt runway at Cana.

Type-specimen. Holotype $q$ (Fig. 3) labeled as "PANAMA: Darien: / Serrania de Pirre: / Cana: 1,000 m / 5 January 1984 / Leg. G.B. Small” [rectangular, white, printed and handwritten], "GENITALIA NO. / 2011: 4069 / C. FAYNEL" [rectangular, green, printed] "Holotype + / Oenomaus gwenish / Robbins \& Faynel, 2012" [rectangular, red, printed]. Deposited in USNM.

Description, diagnosis and recognition as a distinct species. Female FW length: $20 \mathrm{~mm}(N=1)$. Wing pattern (Fig. 3) and genitalia (Fig. 27) illustrated. The wing patterns of $O$. gwenish and $O$. mancha are distinguished from that of $O$. ortygnus by the black patch in the distal part of the VHW cell Sc+R1-Rs and by the absence of a black mark in VFW cell Costa-Sc. However, the ventral wing pattern of O. gwenish differs from that of $O$. mancha by (1) the lack of a black band crossing the VFW discal cell, (2) the absence of a black spot in VFW cell M3-Cu1, and (3) the presence of two black spots of equal size along VHW veins mdc and ldc instead of a single large black spot at vein mdc with no mark or a faint vestigial mark at vein ldc. The female genitalia of $O$. gwenish (Fig. 27) are similar to those of O. mancha.

We hesitated to describe this species because we cannot assess its intraspecific variation. However, the series of 10 females of $O$. mancha show little variation in the traits that distinguish them from the holotype of $O$. gwenish. For this reason, a hypothesis of specific distinctness is better supported than a hypothesis of geographical variation.

Etymology. The holotype of $O$. gwenish is a unique and distinctive female, for which reason it gives us great pleasure to name this species for entomologist Dr. Jennifer (Gwen) Shlichta. The name is a feminine noun in apposition.

Habitat and distribution. Oenomaus gwenish is probably a lower montane species, so far known only from wet forest at $1000 \mathrm{~m}$ elevation in Darién, Panama (Fig. 46). While O. gwenish and O. ortygnus are both known from Panama, we do not know if they are sympatric.

Oenomaus lea Faynel \& Robbins, sp. n.

urn:lsid:zoobank.org:act:A8315354-6FFF-4C71-AEE5-92925AE8833B

http://species-id.net/wiki/Oenomaus_lea

Figs 4, 21, 39, 47

Type-locality. Ecuador: Napo, Misahuallí Rd, Latas Grande, 7.7 km E Puerto Napo, $1^{\circ} 02.0^{\prime} \mathrm{S}, 77^{\circ} 44.1^{\prime} \mathrm{W}, 470 \mathrm{~m}$. The holotype was collected along the road from Tena to Misahuallí, which in 1991 was a patchwork of "fincas" and remnant second growth forest. 
Type-specimen. Holotype $\widehat{~}$ (Fig. 4) labeled as "ECUADOR Napo / Misahualli Rd. 470m / Latas Grande / 9 Nov.' 91 / S. S. Nicolay” [rectangular, white, printed and handwritten], "USNM ENT 00180040" [rectangular, white, printed], "GENITALIA

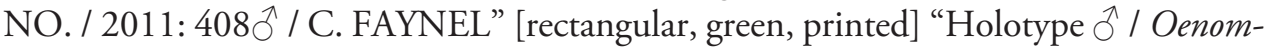
aus lea / Faynel \& Robbins, 2012" [rectangular, red, printed]. Deposited in USNM.

Paratypes: Ecuador. 1 O : La Merced on Río Pastaza below Baños, Alt. $4000 \mathrm{ft}$. [= 1220 m], W. J. Coxey, III.1930, A.N.S. Lot 217, genitalia NO. 1992: 12 § R.K. Robbins (ANSP). Peru. 3 đ: UC, Pucallpa, 200 m, X.2007, Michael Büche leg. (CF); LO, Contamana, Río Ucayali, $300 \mathrm{~m}, 7^{\circ} 19^{\prime} \mathrm{S}, 7^{\circ} 48^{\prime} \mathrm{W}$, IX.2010, leg J. Ramírez (LYD); SM, Juanjui, upper Huallaga River, IX. 1934, collector G. Klug, collection E.I. Huntington NO. 1055 (AMNH).

Description, diagnosis and recognition as a distinct species. Male FW length: $18.2 \mathrm{~mm}(\mathrm{SD}=0.8, N=4)$. Wing pattern (Fig. 4) and genitalia (Fig. 21) illustrated. Oenomaus lea and $O$. atesa (Hewitson, 1867) are the only two Eumaeini sharing the striking underside wing pattern with two transverse brown bands on the VHW. However, males of Oenomaus lea differ from males of O. atesa (Figs 5, 6 in Faynel 2006) by (1) a greater expanse of the DFW blue, especially in the area from vein $\mathrm{R} 3$ to vein $\mathrm{Cu} 1$, (2) two brown patches on the VFW instead of a single median brown band; one patch is located along the costa, and the other is triangular and situated in the basal part of cell $\mathrm{Cu} 1-\mathrm{Cu} 2$, and (3) a lighter dorsal blue color with a different hue of blue along the HW veins M2, M3, Cu1 and Cu2. Moreover, the black spot in VHW cell Cu1-Cu2 is usually more apparent in $O$. atesa than in $O$. lea. Males of $O$. lea also differ genitalically from those of $O$. atesa (Fig. 26 in Faynel 2006) by (1) a longer and wider saccus, (2) the dorsal part of the valvae in lateral aspect shorter than the ventral part, and not pointed at the posterior end, (3) a straight penis in lateral view, and (4) no tooth at the end of the penis. The eighth tergum shows no difference from that of $O$. atesa. Lastly, the divergence of "barcode" DNA sequence data between O. lea (CF-LYC-005) and $O$. atesa (CF-LYC-003) is more than $6 \%$ (Table 1). The female of $O$. lea is unknown.

Etymology. This species is named for Léa Faynel, daughter of Christophe Faynel. The name is a feminine noun in apposition.

Habitat and distribution. Oenomaus lea occurs in wet lowland forest up to 1200 $m$ elevation in eastern Ecuador and eastern Peru (Fig. 47).

\section{Oenomaus myrteana Busby, Robbins \& Faynel, sp. n.} urn:Isid:zoobank.org:act:B8EBB664-61DA-4178-91C8-52D2D9BFF0AC http://species-id.net/wiki/Oenomaus_myrteana

Figs 5, 6, 22, 28, 41, 46

Type-locality. Ecuador: Morona Santiago, Santiago (Hill North of Town), $3^{\circ} 02.3^{\prime} \mathrm{S}$, $78^{\circ} 00.3^{\prime} \mathrm{W}, 350 \mathrm{~m}$. The holotype was collected in wet secondary forest in the low hills on the north edge of Santiago.

Type-specimen. Holotype $\widehat{\delta}$ (Fig. 5) labeled as "ECUADOR: Morona Santiago / Santiago (Hill North of Town) / 302.3'S, 78 00.3'W 350 m / 20 September 2004 / 
Robert C. Busby, leg." [rectangular, white, printed], "GENITALIA NO. / 2003: 35 ${ }^{\lambda}$ / R.K. ROBBINS" [rectangular, green, printed] "Holotype $\delta$ / Oenomaus myrteana / Busby, Robbins \& Faynel, 2012" [rectangular, red, printed]. Deposited in USNM.

Paratypes: Ecuador. 1 $\delta^{\Uparrow}$ : Morona Santiago, Santiago (Hill North of Town), $3^{\circ} 2.3^{\prime} \mathrm{S}, 78^{\circ} 0.3^{\prime} \mathrm{W}, 350 \mathrm{~m}, 20 . \mathrm{IX} .2006$, Robert C. Busby leg. (RCB) ; 1 \%: MoronaSantiago Province, $1.8 \mathrm{~km}$ Santiago-Puerto Morona Rd., 3².4' $\mathrm{S}, 77^{\circ} 59.7^{\prime} \mathrm{W}, 300$ 350 m, 20.IX.2006, D.H. Ahrenholz \& Robert C. Busby leg., gen. prep. CF n 415 (RCB) (Fig. 6). Brazil. 2 đ: RO, Cacaulândia, 1-5.IX.1997, E. Furtado \& A. Moser leg., gen. prep. CF n442 (MC 250); RO, Candeias do Jamari, Rio Preto, 27-31. VIII.1997, E. Furtado \& A. Moser leg., gen. prep. CF n 443 (MC 251).

Description, diagnosis and recognition as a distinct species. Male FW length: $12.8 \mathrm{~mm}(\mathrm{SD}=0.1, N=3)$. Female FW length: $12.1 \mathrm{~mm}(N=1)$. Wing pattern (Figs $5,6)$ and genitalia (Figs 22, 28) illustrated. Oenomaus myrteana has a conspicuous round white spot in VHW cell $\mathrm{Sc}+\mathrm{R} 1-\mathrm{Rs}$, which is similar to those species of Oenomaus with a ventral wing patterns similar to that of $O$. atena. However, O. myrteana lacks the inclined white median line of the VFW, which is characteristic of species with the $O$. atena wing pattern. Instead, $O$. myrteana has a vertical, distally displaced postmedian line of white dashes, inwardly bordered by black. This character appears to be unique among Oenomaus species. In addition, O. myrteana may have a few redorange scales in $\mathrm{VHW}$ cell $\mathrm{Cu} 1-\mathrm{Cu} 2$. This red-orange cubital spot is uniformly lacking in other Oenomaus and Porthecla. The male genitalia of O. myrteana are very similar to those of $O$. nigra, which has an "atena-like" ventral wing pattern. The female genitalia of $O$. myrteana are similar to those Oenomaus that have a bifid posterior end of the ductus bursae and a signa with a two pointed spine in the middle of the corpus bursae.

The ventral wing pattern of $O$. myrteana is superficially similar to those of Enos myrtea (Hewitson) and Allosmaitia myrtusa (Hewitson), but in these genera, males lack a scent pad on the DFW. The genitalia of $O$. myrteana, as noted, are typical of Oenomaus.

Etymology. The name $O$. myrteana is intended to highlight the striking resemblance between the ventral hindwing of this species and that of Enos myrtea (Hewitson). The name is a feminine noun in apposition.

Habitat and distribution. Oenomaus myrteana occurs in lowland wet forest from eastern Ecuador to western Brazil (Rondônia) (Fig. 46). Busby observed males in Ecuador low in the understory at 11:00 hours. This species and E. myrtea have been found at the same site.

\section{Oenomaus mentirosa Faynel \& Robbins, sp. n.} urn:Isid:zoobank.org:act:FDD83214-61B2-4B8A-B468-984D9DA0560D http://species-id.net/wiki/Oenomaus_mentirosa Figs $7,23,40,47$

Type-locality. Peru: Madre De Dios, Río La Torre, Tambopata Res., 1250'13"S, $69^{\circ} 17^{\prime} 35^{\prime \prime} \mathrm{W}, 300 \mathrm{~m}$. Tambopata is at the mouth of the Río La Torre. In 1986 there was a lodge and a network of trails through uncut wet lowland forest. The holotype 
was collected during the transition between the dry and wet seasons when butterfly abundance and diversity generally peak.

Type-specimen. Holotype $\widehat{\partial}$ (Fig. 7) labeled as "PERU Madre De Dios / Rio La Torre 300m / Tambopata Res. / 3 Oct.' 86 / S. S. Nicolay” [rectangular, white, printed and handwritten], "GENITALIA NO. / 2011: 409 / C. FAYNEL" [rectangular, green, printed] "Holotype $\widehat{O}$ / Oenomaus mentirosa / Faynel \& Robbins, 2012" [rectangular, red, printed]. Deposited in USNM.

Paratypes: Peru. 4 đ : LO, km 28, Iquitos-Nauta, 180 m, 0359/7326, 30.X.2003, J.J. Ramírez leg. (MUSM) ; MD, Boca Río La Torre, 300 m, 17.IX.1984, I. Bohórquez leg., Genitalia NO. 1992: 47仓 R.K. Robbins (MUSM); MD, Boca Río La Torre, 300 m, 27.X.1981, G. Lamas et al., Genitalia NO. 1992: 48ð R.K. Robbins (MUSM) ; MD, Tambopata Reserve, 1250'S, 69¹7'W, 300 m, 27.X.1990, Leg. R. Robbins, Genitalia NO. 1992: 39 $ત$ R.K. Robbins (USNM ENT 00180049).

Description, diagnosis and recognition as a distinct species. Male FW length: $14.9 \mathrm{~mm}(\mathrm{SD}=0.3, N=2)$. Wing pattern (Fig. 7$)$ and genitalia (Fig. 23) illustrated. The ventral wing pattern of $O$. mentirosa is very similar to some species of the Porthecla gemma group (Faynel et al. 2011), but the male genitalia have the non-triangular bifurcate valvae in lateral aspect that are characteristic of Oenomaus. Its genitalia, especially the valvae, are very similar to those of $O$. cortica (D'Abrera) and $O$. druceus Faynel \& Moser. Oenomaus mentirosa is the only known Oenomaus species with red scales at the base on the VHW. In addition, it has a distinctive white spot along the VFW costa in cell Sc-R1. This feature occurs in no other Eumaeini except Porthecla minyia (Hewitson) where there are two white markings placed side by side in the cell between the costa and Sc. In male Oenomaus species, the eighth tergum is generally rectangular, but the anterior and posterior edges may be modified. In O. mentirosa, the male eighth tergum has a slightly modified anterior edge which looks like a shallow "W". The female of $O$. mentirosa is unknown.

Etymology. The name of this species comes from the Spanish word 'mentirosa', which means a feminine liar. We picked this name because the underside wing pattern resembles that of Porthecla gemma (Druce) and P. minyia (Druce), but this resemblance appears to be a false indicator of relationship. We treat the name as a feminine noun in apposition.

Habitat and distribution. Oenomaus mentirosa is known from lowland wet forest in Amazonian Peru (Fig. 47).

Remarks. Resemblance of the ventral wing patterns of $O$. mentirosa and $P$. gemmal $P$. minyia was noted in the etymology. Adults of all three species fly in the same habitats at the same time of year in the vicinity of Puerto Maldonado, Peru.

\section{Oenomaus andi Busby \& Faynel, sp. n.} urn:lsid:zoobank.org:act:C6C09BC9-F0B9-4E7A-8951-0D9923BE9E73 http://species-id.net/wiki/Oenomaus_andi Figs 8, 9, 24, 29, 42, 43, 47

Type-locality. Ecuador: Zamora Chinchipe Prov., Zamora (ridge W. of town), $4^{\circ} 04.5^{\prime} \mathrm{S}, 78^{\circ} 58.1^{\prime} \mathrm{W}, 1450 \mathrm{~m}$. The ridge west of Zamora rises rather sharply from 
the city and is accessed by a dirt road which goes up to about $1300 \mathrm{~m}$. The top of the ridge is still forested but a significant part of the surrounding land has been turned into pasture.

Type-specimen. Holotype $\widehat{\diamond}$ (Fig. 8) labeled as "ECUADOR / Zamora Chinchipe Prov. / Zamora (ridge W. of town) / 18. ix. 2000 (1450m) / leg. Robert C. Busby" [rectangular, white, printed], "GENITALIA NO. / 2009: 3440 / C. FAYNEL" [rectangular, green, printed] "Holotype $\hat{\sigma} /$ Oenomaus andi / Busby \& Faynel, 2012" [rectangular, red, printed]. Deposited in USNM.

Paratypes: Ecuador. 3울 Morona-Santiago, $1 \mathrm{~km}$ E Río Abanico, $1600 \mathrm{~m}$, $2^{\circ} 15.4^{\prime} S ; 78^{\circ} 11.7^{\prime} \mathrm{W}, 15 . \mathrm{IX} .2003$, Robert C. Busby leg., gen. prep. CF nº16 (RCB) (Fig. 9) ; Morona-Santiago, 14 km W. of Macas, 1600m, 28.IX.1998, Río Abanico, leg. Robert C. Busby (RCB); Zamora Chinchipe, Zamora (ridge W. of town), $4^{\circ} 04.5^{\prime}$ S, $78^{\circ} 58.1^{\prime} \mathrm{W}, 1450$ m, 06.X.2007, D. H. Ahrenholz, R. C. Busby leg. (RCB).

Other specimen examined. Bolivia. 1 9 : La Paz, Nor Yungas, Caranavi, $1500 \mathrm{~m}$, XII. 2004, gen. prep. CF nº45 (MC 253).

Description, diagnosis and recognition as a distinct species. Male FW length: $16.3 \mathrm{~mm}(N=1)$. Female FW length: $16.7 \mathrm{~mm}(\mathrm{SD}=0.8, N=2)$. Wing pattern (Figs 8,9) and genitalia (Figs 24,29) illustrated. The ventral wing pattern of $O$. andi is similar to that of many other Oenomaus, but this species is distinguished by (1) a white spot on the basal side of VHW cell Rs-M1, (2) an elongated double valvae of equal size, (3) a large posterior part of the saccus in lateral view, (4) a swollen terminal end of the penis, and (5) modified anterior and posterior edges of the male 8th tergum (detailed under remarks).

Etymology. This species is named for Andrea (Andi) Busby, wife of Robert Busby, in appreciation for her long standing support of his research. The name is a feminine noun in apposition.

Remarks. Valvae structure in $O$. andi is very similar to that found in O. gaia Faynel, suggesting that this new species belongs to the $O$. cortica subgroup (as characterized by Faynel and Moser 2008). Species in this subgroup have a modified 8th tergum (except for $O$. druceus Faynel \& Moser, 2008). In the male of $O$. andi (Fig. 42), the posterior edge of the 8 th tergum has a deep depression in the middle, while the anterior edge is shaped like a wide "W". In the female, the posterior edge is nearly straight but is split in the middle. The anterior edge is similar to that of the male, but is laterally sclerotized (Fig. 43). The white spot on the basal side of VHW cell Rs-M1 occurs in only a few other Oenomaus species including O. geba (Hewitson), O. melleus (Druce), O. morroensis Faynel \& Moser, and O. jauffreti Faynel \& Moser. Regardless of whether the presence of this spot is evidence of relationship, it is very useful for separating $O$. andi from the other species of the $O$. cortica subgroup.

Habitat and distribution. Oenomaus andi is a species of montane forest (> 1300 $\mathrm{m})$ that is recorded from Ecuador to Bolivia (Fig. 47).

Behavior. A male and two females were attracted to traps baited with rotting fish (vouchers in RCB). 
Oenomaus moseri Robbins \& Faynel, sp. n. urn:Isid:zoobank.org:act:DC5D1BF6-2149-4BB9-802D-58C27D11AB38 http://species-id.net/wiki/Oenomaus_moseri Figs 10, 11, 25, 30, 44, 45, 46

Type-locality. Brazil: SC, Joinville, 26ำ19'39"S, 4857'38"W, 10-200 m. Miers collected butterflies for decades in the wet lowland forests around Joinville, where he lived. His favorite collecting spot was a hill that he called "Serrinha" (little hill in Portuguese) in Vila Nova, approximately $10 \mathrm{~km}$ west, south-west of the center of Joinville. According to DZUP butterfly curator Olaf Mielke, specimens collected on Serrinha, including the holotype, have an elevation label 10-200 m, which distinguishes them from those specimens collected in other parts of the Joinville area.

Type-specimen. Holotype $\widehat{\partial}$ (Fig. 10): Brazil, SC, Joinville, 10-200 m, 2.IV.1978, Miers leg., gen. prep. CF n²18, DZ 10.065, CF-LYC-012 (DZUP).

Paratypes: Brazil. 12 đ: SC, Joinville, $200 \mathrm{~m}, 26^{\circ} 19^{\prime} \mathrm{S}, 48^{\circ} 58^{\prime} \mathrm{W}, 20 . \mathrm{V} .1971$, H.Miers leg., gen. prep. CF n444 (MC 252) ; SC, São Bento do Sul, 600 m, 25.IV.2002, Moser \& Rank leg., gen. A. Moser, n²34 (MC 034); SC, Joinville, 200 m, 5.II.1993, A. Moser leg., gen. A. Moser, n²26 (MC 032); SC, Joinville, 200 m, 5.II.1993, A. Moser leg., gen. A. Moser n²33 (MC 033) ; SC, Joinville, 10-200 m, 8.XII.1983, Leg. H. Miers, R.K. Robbins collection (USNM) ; SC, Joinville, 10-200 m, 6.I.1984, Leg. H. Miers, R.K. Robbins collection (USNM) ; PR, Ponta Grossa, Buraco do Padre, 900 m, 20.II.2009, Carlos Mielke leg., CF-LYC-063 (CF) ; SP, Serra do Japi, $110[0 \mathrm{~m}], 23^{\circ} 15^{\prime}$ S, $46^{\circ} 54^{\prime} \mathrm{W}, 12 . \mathrm{IV} .1991$, Robbins $\&$ K. Brown, territorial behavior at 14:23, Genitalia NO. 1992: 27 $ठ^{\Uparrow}$ R.K. Robbins (USNM) ; SP, Serra do Japi, $110[0] \mathrm{m}, 23^{\circ} 15^{\prime} \mathrm{S}, 46^{\circ} 54^{\prime} \mathrm{W}, 12 . I V .1991$, Robbins \& K. Brown, territorial behavior at 14:48 (USNM) ; SP, Serra do Japi, 800-1250 m, 2312'-17'S, 46 $53^{\circ}-$ $47^{\circ} 02^{\prime} \mathrm{W}, 25 . I I I .1990$, Leg. K. Brown (x2, USNM) ; SP, Serra do Japi, 800-1250 m, $23^{\circ} 12^{\prime}-17^{\prime}$ S, $46^{\circ} 53^{\prime}-47^{\circ} 02^{\prime} \mathrm{W}, 28 . I I I .1990$, Leg. K. Brown (USNM) ; RJ, Petrópolis, 6.I.1980, Leg. C. Callaghan, R.K. Robbins collection, Genitalia NO. 1992: 79ð R.K. Robbins (USNM ENT 00180045). 1 오 SC, Joinville, 10-200 m, 9.III.1973, Leg. H. Miers, R.K. Robbins collection, gen. prep. CF n410 (USNM) (Fig. 11).

Description, diagnosis and recognition as a distinct species. Male FW length: $16.1 \mathrm{~mm}(\mathrm{SD}=0.9, N=8)$. Female FW length: $15.7 \mathrm{~mm}(N=1)$. Wing pattern (Figs 10, 11) and genitalia (Figs 25,30) illustrated. The adult wing pattern of $O$. moseri is similar to that of the sympatric $O$. morroensis Faynel \& Moser and to that of O. cyanovenata (D'Abrera); the species with which it was previously confused (Faynel 2008). Oenomaus moseri (Figs 25, 45) differs from O. morroensis (plate 11 in Faynel and Moser 2008) by its male genitalia having (1) a smaller dorsal part of the valvae attached to the top of the ventral part, not to the bottom, (2) a swollen posterior part of the male penis, and (3) a larger posterior part of the saccus in lateral view. Oenomaus moseri differs from O. cyanovenata by (1) a wider DFW black margin at the tornus, (2) a central depression on the posterior edge of the eighth tergum, and (3) a swollen posterior part of the male penis. Oenomaus moseri differs from the sympatric O. geba 
by lacking a white spot on the basal side of VHW cell Rs-M1 (Figs 10-12). The lack of geographical variation in the characters distinguishing $O$. moseri and $O$. cyanovenata argues against the hypothesis that the former is a geographical variant of the latter.

Preliminary data on divergence of "barcode" DNA sequence data is consistent with morphology. The divergence among three individuals of O. moseri (CF-LYC-012 \& CF-LYC-063) is 0\%, among four individuals of O. cyanovenata (CF-LYC-047, CF-LYC-048, \& CF-LYC-049) is $0 \%$. In contrast, the divergence between $O$. moseri and $O$. cyanovenata is more than $4 \%$ and between two $O$. moseri and a paratype of $O$. morroensis (CF-LYC-015) is more than 5\%.

Etymology. It is with great pleasure that we name this distinctive species for our good friend and collaborator Alfred Moser. Alfred lives in Rio Grande do Sul and has made prodigious contributions to the knowledge of Lepidoptera from southern Brazil, including co-authoring papers on the taxonomy of Oenomaus and Porthecla (Faynel and Moser 2008, Faynel et al. 2011).

Biology. Robbins observed two males of $O$. moseri exhibiting territorial behavior on a hill top from 14:23 hours to 14:48 hours at Serra do Japi (SP, Brazil) on 12 April 1991 (vouchers in USNM). A male of Oenomaus moseri was reared by Hipólito Ferreira Paulino Neto in Itirapina, SP, Brazil on Duguetia furfuracea (A. St. Hil) Benth. and Hook. f. (Annonaceae), a plant of frequent occurrence in the cerrado. We identified the male from a digital image and from the locality where it was reared. However, it is possible that it is a male of $O$. morroensis, even though this species is not known to occur as far north as São Paulo.

Habitat and distribution. Oenomaus moseri occurs in lowland and lower montane forest in southern Brazil (Fig. 46).

\section{New data for previously described species of Oenomaus}

For each of the 21 previously described Oenomaus species, we give distribution, habitat, and remarks. We then note, where relevant, new information on taxonomy, intraspecific variation, behavior/biology, associated females, and COI DNA sequences. The species are treated in alphabetical order. Oenomaus curiosa and O. melleus are included in this section, even though their generic placement is yet unresolved (Faynel et al. 2011).

\section{Oenomaus ambiguus Faynel}

http://species-id.net/wiki/Oenomaus_ambiguus

Distribution, habitat, and remarks. Oenomaus ambiguus is a poorly known, lowland species whose ventral wing pattern is virtually indistinguishable from those of $O$. cortica and O. gaia. It has been recorded from French Guiana and Amazonian Peru. The previous record from Amazonas, Brazil (Faynel 2008) was incorrect. 


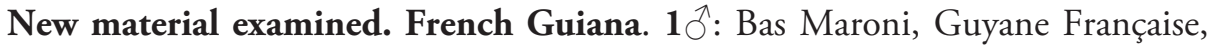
gen. prep. CF n³19 (MNHN H-452). Peru.-1 ${ }^{\Uparrow}$ : MD, Río La Torre, 300 m, Tambopata Res., 27.IX.1987, S.S. Nicolay, gen. prep. CF n404 (USNM).

Female. Unknown.

COI DNA sequence. The paratype from Peru has been barcoded (CF-LYC-025), and the sequence is $2-3 \%$ divergent from those of $O$. cortica, O. gaia and $O$. morroensis (Table 1).

\section{Oenomaus atena (Hewitson)}

http://species-id.net/wiki/Oenomaus_atena

Distribution, habitat, and remarks. Oenomaus atena is a widely distributed lowland species that is reliably recorded from Costa Rica, Panama, western Ecuador, French Guiana, Venezuela, Peru, and Brazil (AM, MT). Most species with an "atena-like" ventral wing pattern have historically been identified as $O$. atena, which means that virtually all literature records for $O$. atena from before 2005 are unreliable.

New material examined. Costa Rica.- 1 $\delta^{\Uparrow}$ : Guápiles, $850 \mathrm{ft}$. alt., June, Schaus and Barnes coll., genitalia on slide X-10-1946, W.D.F. 2333 (USNM). Panama.- $1 \overbrace{}^{\Uparrow}$ : Cerro Campana, 2000', XII-22-1963, G.B. Small, Genitalia 1992: $15 \overbrace{}^{\wedge}$ R.K. Robbins (USNM). Ecuador.- 1 $\delta^{\top}$ : Esmeraldas, $25 \mathrm{~km}$ San Lorenzo-Lita Road, $1^{\circ} 10.0^{\prime} \mathrm{N}$, 7840.0'W, 100 m, VI.2003, San Francisco, R. Aldas \& Robert C. Busby leg., gen. prep. CF n³43 (RCB). Peru.- 2§̃: MD, 30 km S.W. Pto. Maldonado, 300 m, 20.X.1983, S.S. Nicolay, Genitalia 1992: $16 \overbrace{}^{\lambda}$ R.K. Robbins (USNM); MD, $10 \mathrm{~km}$ north Puerto Maldonado, $200 \mathrm{~m}, 12^{\circ} 36^{\prime} \mathrm{S}, 69^{\circ} 11^{\prime} \mathrm{W}, 26-30 . X I .1993$, leg. C. Tello (USNM).

Female. The female of this species was determined by a pair collected in copula and was illustrated by Faynel (2008, fig. 2).

COI DNA sequence. Three specimens of $O$. atena have been barcoded, including a male from Peru (LO) (CF-LYC-084) and two females from French Guiana (CFLYC-054 and CF-LYC-057). The latter two have the same brown dorsal wing pattern, ventral wing pattern, and genitalia as the female of $O$. atena found in copula. The three barcodes show $0.4 \%$ divergence.

\section{Oenomaus atesa (Hewitson)}

http://species-id.net/wiki/Oenomaus_atesa

Distribution, habitat, and remarks. Oenomaus atesa is a widespread species that has been recorded from Mexico, Panama, western Ecuador, French Guiana, Venezuela, Colombia, eastern Ecuador, Peru, and Brazil (AM, DF, MG, RJ, SP, SC). The vast majority of museum specimens were collected in the lowlands, but males have also been found at $1375-1700 \mathrm{~m}$ in western Ecuador and at $2200 \mathrm{~m}$ in western Colombia (Prieto and Dahners 2006). 
New material examined. Venezuela.- 19 : Venezuela, Aragua, Rancho Grande, 1100 m, 29.V.1985, S.S. Nicolay leg., gen. prep. CF nº404 (USNM). Ecuador.20: Pichincha $5 \mathrm{~km}$ Nanegal-García Moreno Rd, 009.2'N, 78³9.4'W, 4.VI.2008, 1375-1700 m, Robert C. Busby leg., gen. prep. CF n³40 (RCB); Napo Province, $14 \mathrm{~km} \mathrm{~S}$ of Tena, 17-18.X.1996, 600 m, Robert C. Busby leg., gen. prep. CF n ${ }^{\circ} 347$ (RCB). 1 \% : Río Chuchuví, Lita vers San Lorenzo km12, $700 \mathrm{~m}$ (provincia de Esmeraldas), VIII.2001, Euclides Aldaz leg. (PB). Peru.- 1\%: LO, 180 m, San Salvador, 5 km NNW Contamana, 08¹9'S, 7501'W, 27.XI.2002, D.H. Ahrenholz leg., gen. prep. CF n 403 (USNM). Brazil.- 1 ${ }^{\top}$ : DF, Parque do Gama, 950 m, 14.V.1969, S.S. Nicolay leg., gen. prep. CF n405 (USNM ENT 00180586).

Intraspecific variation. Despite substantive geographical variation in $O$. atesa, we lack sufficient material to determine if this variation might represent more than one species. Females from Venezuela and western Ecuador have more extensive dorsal blue and a somewhat lighter color than females from Panama, French Guiana, eastern Ecuador, and Peru. In addition, males from western Ecuador have more blue on the dorsal forewings than males from eastern Ecuador. However, this variation is small compared to that between males of $O$. atesa and $O$. lea. For example, the forewing dorsal blue area never reaches the cells from vein $\mathrm{R} 3$ to $\mathrm{Cu} 1$ as it does in $O$. lea. Structure of the female genitalia also varies geographically. Females from Venezuela and Peru have two processes at the posterior end of the lamella postvaginalis while a female from French Guiana had none (see Faynel 2006, p. 29).

Behavior/biology. Males exhibited territorial behavior on a hilltop in Panama (Canal Area, Gamboa, Cerro Pelado) from 13:15 to 15:30 hours (19 males, 10 different days during the months of January, February, March, April, August, September, October, and December, 15 vouchers in USNM). Similarly, territorial males on a hilltop in Brazil (Santa Catarina, Villa Nova, Serrinha) were observed from 14:40 to 14:55 hours (3 males, March, 3 vouchers in USNM).

Female. Females are associated with males by their ventral wing pattern, which is unique among the Eumaeini. Characters were noted for distinguishing the ventral wing pattern of $O$. atesa from that of $O$. lea.

COI DNA sequence. One male of $O$. atesa from French Guiana has been barcoded (CF-LYC-003).

\section{Oenomaus brulei Faynel}

http://species-id.net/wiki/Oenomaus_brulei

Distribution, habitat, and remarks. Faynel (2008) described O. brulei from one male collected in the lowlands of French Guiana. Since then, another male and female from French Guiana have been examined.

New material examined. French Guiana.- $1{ }^{\lambda}$ : Guyane, no date, S. Fernandez leg., CF-LYC-033 (CF). 1 \% : Montagne des Singes, 507'N, 5269'W, 5.XII.2007, T. Rosant leg., gen. prep. CF n440, CF-LYC-034 (CF) (Fig. 14). 

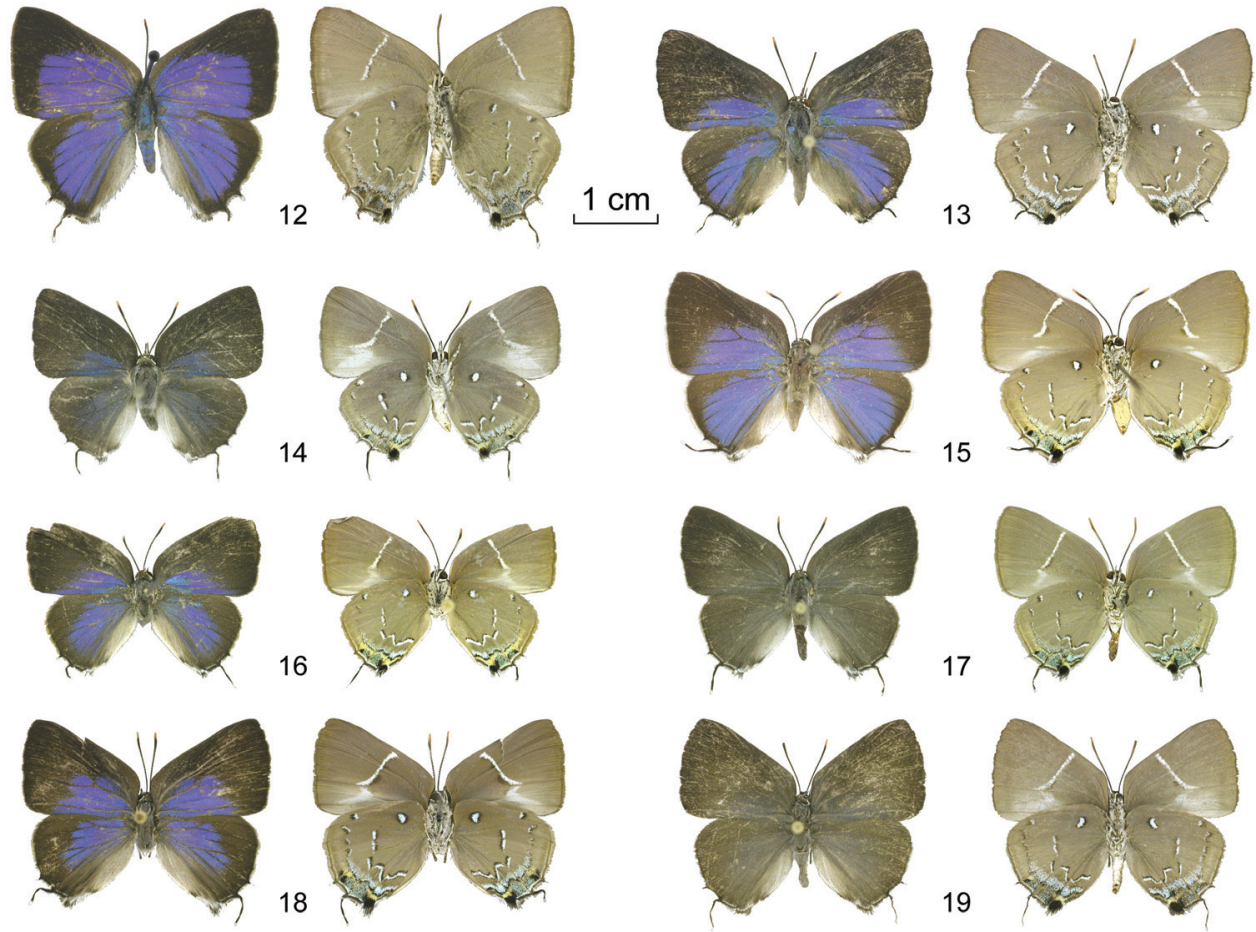

Figures 12-19. Oenomaus, newly associated females: adults (dorsal surface at left, ventral surface at right). 12 O. geba (Brazil) I3 O. magnus (French Guiana) I4 O. brulei (French Guiana) I5 O. gaia (Panama) 16 O. cyanovenata (Costa Rica) 17 O. cyanovenata (French Guiana) I8 O. taua (Panama) 19 O. taua (Ecuador).

Female. We associate a female (Figs 14,31) which has the same ventral wing pattern as the male, which occurs in French Guiana (as do the known males), and which has a very similar COI DNA sequence to that of the males.

COI DNA sequence. Divergence among the three known specimens is $0.2 \%$.

\section{Oenomaus cortica (D'Abrera)}

http://species-id.net/wiki/Oenomaus_cortica

Distribution, habitat, and remarks. This species occurs in wet lowland forest and is recorded from Panama, Guyana, Peru, and Brazil (PA, AM). Oenomaus cortica, O. gaia, and $O$. ambiguus have very similar wing patterns, but their genitalic structures are distinct.

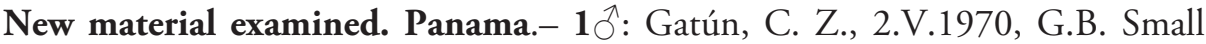
leg., Genitalia 1992: 13ð R.K. Robbins (USNM). Guyana.- 1 ${ }^{\Uparrow}$ : Potaro Riv., VIIIIX.1902, C.B. Roberts, Genitalia 1992: $74 \overbrace{}^{\Uparrow}$ R.K. Robbins (FSMC). Peru.- $1{ }^{\Uparrow}$ : MD,

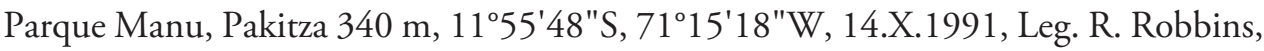
Genitalia No. 1996: $3{ }^{\Uparrow}$ R.K. Robbins (USNM ENT 00180044). 
Intraspecific variation. The male from Panama has the posterior edge of its 8th tergum more deeply incised than in others.

Female. Unknown. A female paratype of O. cortica from Espírito Santo, Brazil was illustrated in D'Abrera (1995), but no definitive evidence was presented to support this identification.

COI DNA sequence. Two males from Brazil, Pará have been sequenced (CFLYC-051 and CF-LYC-052) and show $0.6 \%$ divergence.

\section{Oenomaus curiosa Faynel \& Moser}

http://species-id.net/wiki/Oenomaus_curiosa

Distribution, habitat, and remarks. Oenomaus curiosa is a species of wet lowland forest that is recorded from French Guiana, Peru (LO, MD), and Brazil (RO).

New material examined. Peru.- 2 : MD, $300 \mathrm{~m}, 30 \mathrm{~km} \mathrm{~S}$. W. Pto Maldonado, 26.X.1983, S.S. Nicolay, Genitalia No. 1992: 250ึ R.K. Robbins (USNM); LO, 120 m, Pebas, river Amazonas, 0319'S, 71 $51^{\prime} \mathrm{W}$, II. 2011, Ramírez leg. (CF). Brazil.1 个: RO, $62 \mathrm{~km} \mathrm{SW}$ Ariquemes, Línea 20, lot 21, 23, 25 (Fazenda Rancho Grande), 11.X.1993, AVZ Brower, gen. prep. CF n433 (OSAC).

Female. Unknown

COI DNA sequence. Two males from French Guiana, including one of the paratypes, have been sequenced (CF-LYC-036 and CF-LYC-037) and show $0.8 \%$ divergence.

\section{Oenomaus cyanovenata (D'Abrera)}

http://species-id.net/wiki/Oenomaus_cyanovenata

Distribution, habitat, and remarks. A species of very wet lowland forest, it has been recorded from Costa Rica, Panama, French Guiana, Venezuela, Bolivia, and Brazil (PA, AM). The previous record for Brazil (SC) was incorrect; this specimen is now treated as $O$. moseri.

New material examined. Costa Rica.- 1 ${ }^{\lambda}$ : Guápiles, $850 \mathrm{ft}$. alt., Schaus and Barnes coll., Genitalia 1992: 76へ R.K. Robbins (USNM); 2 ? : Area de Conservación Guanacaste, voucher: D.H. Janzen \& W. Hallwachs 97-SRNP-62841.1, Genitalia 2009: 309 R.K. Robbins (USNM) (Fig. 16); 97-SRNP-6283. Panama.- 1 ${ }^{\widehat{T}}$ : Colón, Piña, 100 m, 9.IV.1971, H.L. King, genitalia slide/vial \#4710, prep. S.S. Nicolay (USNM). French Guiana.- 3 9 : Roura, Route de Kaw - PK 16, 18.VII.2004, C. Faynel leg., CF-LYC-053 (CF); Roura, Route de Kaw, 26.I.2005, J.Y. Gallard leg., gen. prep. CF n441, CF-LYC-055 (CF) (Fig. 17); Roura, Route de Kaw - PK 8, 20.XII.2001, J.Y. Gallard leg., CF-LYC-056 (CF). Brazil.- 3 + : PA, Santo Antônio do Tauá, Reserva Sonho Azul, $1^{\circ} 15^{\prime}$ S, $48^{\circ} 03^{\prime} \mathrm{W}, 12$. VI.2009, P. \& J. Jauffret leg., CF-LYC-059 (CF); PA, Santo Antônio do Tauá, Reserva Sonho Azul, $1^{\circ} 15^{\prime}$ S, $48^{\circ} 03^{\prime} \mathrm{W}, 3$.VIII.2009, P. \& J. Jauffret leg., CF-LYC-060 (CF); PA, Santo Antônio do Tauá, Reserva Sonho Azul, $1^{\circ} 15^{\prime}$ S, 480'' $\mathrm{W}, 8 . V .2009$, P. \& J. Jauffret leg., CF-LYC-061 (CF). 

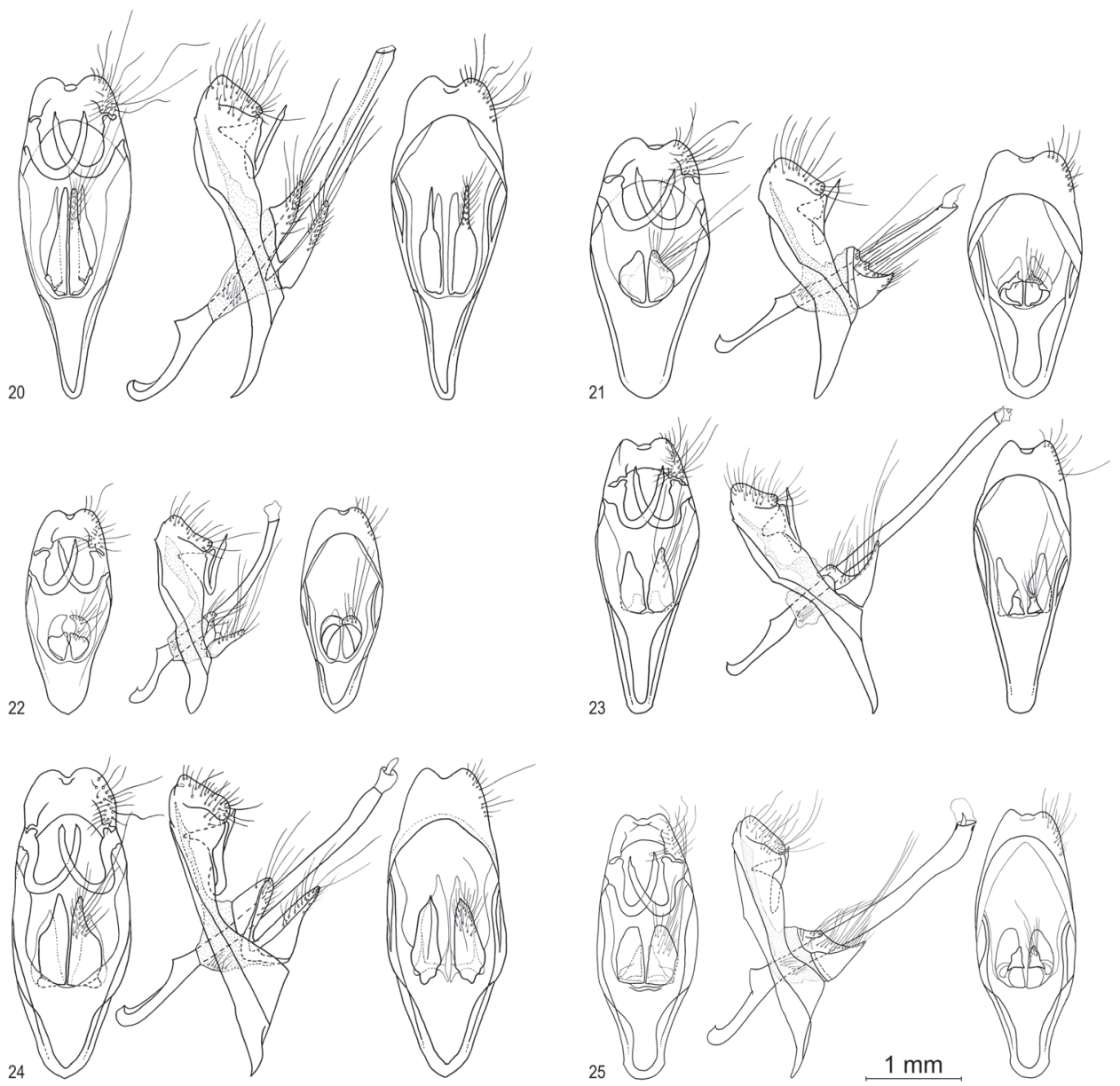

Figures 20-25. Oenomaus male genitalia: ventral view at left (setae drawn only on the right side and penis removed), left lateral view in the middle (with the penis and valvae displaced $-45^{\circ}$ to make them more visible), and dorsal view at right (with setae drawn only on the right side and penis removed). 20 O. mancha (holotype, Ecuador) 21 O. lea (holotype, Peru) 22 O. myrteana (holotype, Ecuador) 23 O. mentirosa (holotype, Peru) 24 O. andi (holotype, Ecuador) 25 O. moseri (holotype, Brazil).

Intraspecific variation. Females from French Guiana and Brazil, Pará (Fig. 17) are uniformly brown on the dorsal wing surface while the female from Costa Rica (Fig. 16) has the basal parts of both wings blue. Their genitalia, however, are uniform. Additionally, their COI DNA sequences are similar. This geographic variability is similar to that in $O$. taua.

Behavior/biology. Two females were reared in Costa Rica (97-SRNP-62841.1 and 97-SRNP-6283) from Guatteria verrucosa R.E. Fr. (Annonaceae) (adult vouchers in USNM). Details of the rearing records along with images of the immatures can be found in Janzen and Hallwachs (2012).

Female. Females of this species (Figs 16, 17, 32, 33) have the same ventral wing pattern as males, occur at the same localities, and have similar COI DNA sequences. 

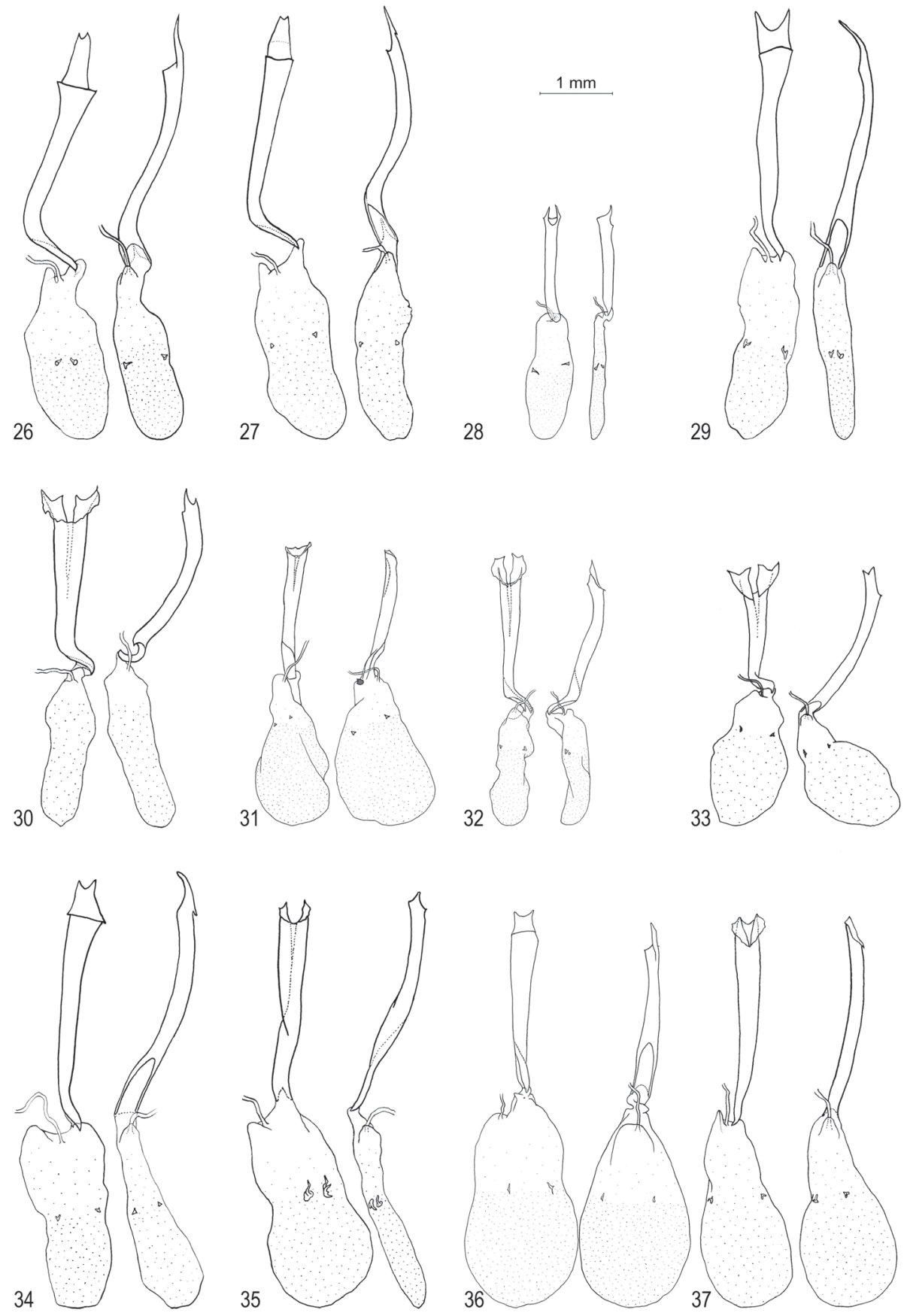

Figures 26-37. Oenomaus female genitalia: ventral view at left, lateral view on right. 26 O. mancha (paratype, Ecuador) 27 O. gwenish (holotype, Panama) 28 O. myrteana (paratype, Ecuador) 29 O. andi (paratype, Ecuador) 30 O. moseri (paratype, Brazil) 31 O. brulei (French Guiana) 32 O. cyanovenata (French Guiana) 33 O. cyanovenata (Costa Rica) 34 O. gaia (Panama) 35 O. geba (Brazil) 36 O. magnus (French Guiana) 37 O. taua (Panama). 


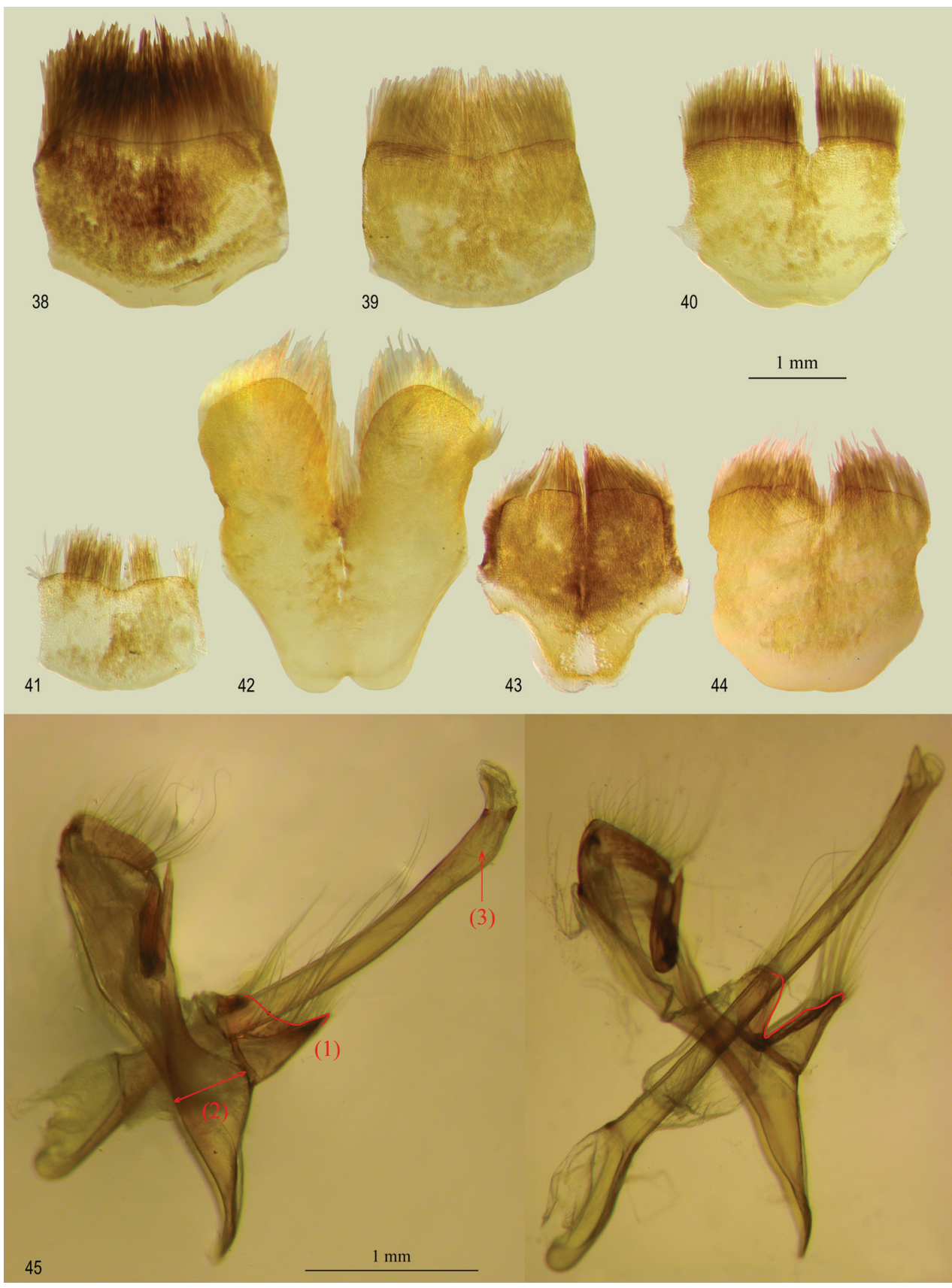

Figures 38-45. Oenomaus, eighth abdominal tergum: ventral view, anterior edge at bottom. $38 \AA 0$.

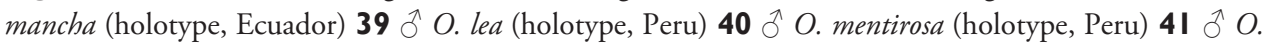
myrteana (holotype, Ecuador) 42 $\bigcirc$ O. andi (holotype, Ecuador) 43 + O. andi (paratype, Ecuador) $44 \hat{\jmath}$ $O$. moseri (holotype, Brazil) 45 Male genitalia in lateral view: $O$. moseri (left) and $O$. morroensis holotypes. Diagnostic characters (1), (2) and (3) are explained in the text. 


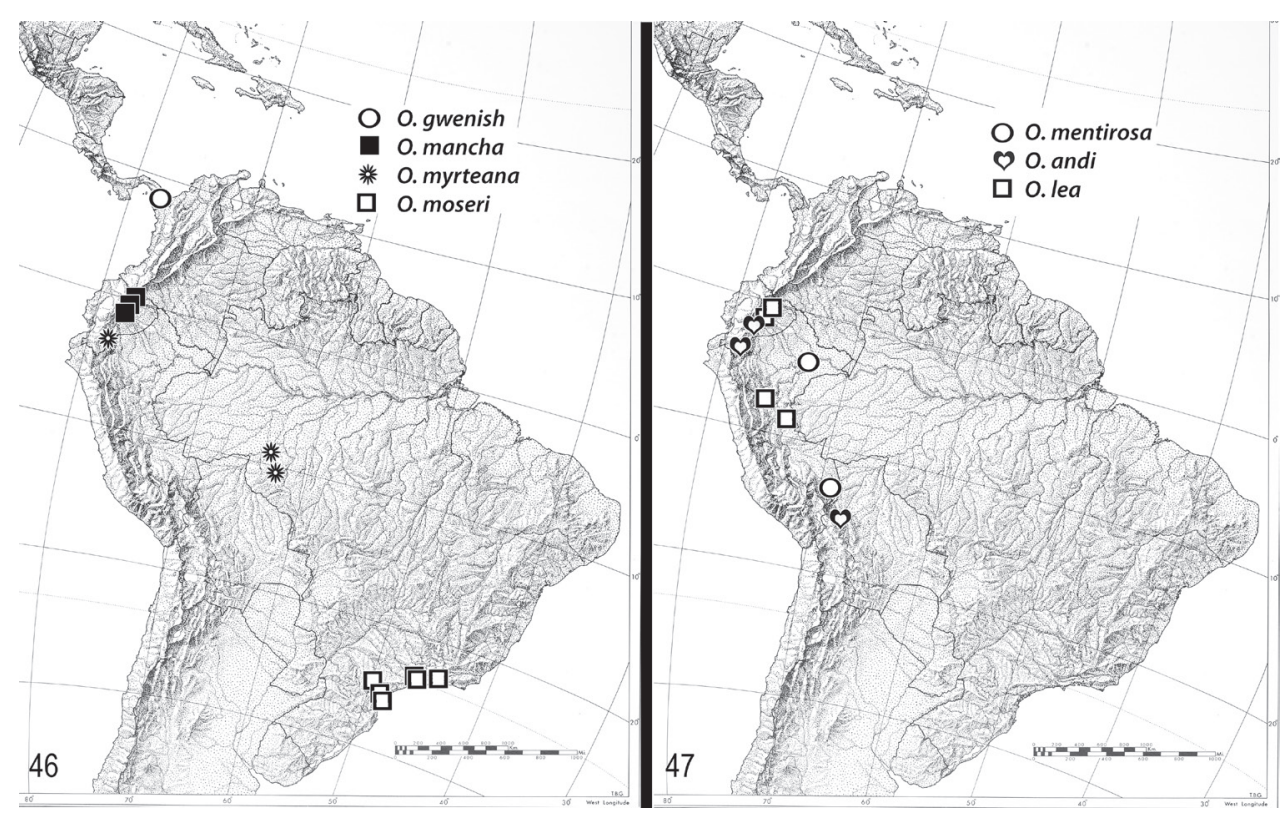

Figures 46-47. Distributions. 46 O. mancha, O. gwenish, O. myrteana, O. moseri 47 O. andi, O. lea, O. mentirosa.

A female paratype of $O$. cyanovenata from Pará, Brazil was designated and illustrated in D'Abrera (1995) without definitive supporting evidence. This female has a different dorsal wing pattern than the female from Pará that we have associated with the male. We are skeptical of the biological validity of this paratype designation.

COI DNA sequence. Four males and seven females from French Guiana and Brazil, Pará were barcoded. One male (CF-LYC-046) is 6.7\% divergent from the other three males, but its sequence is identical with that from a male of $O$. magnus (CFLYC-020). Potential explanations for this result range from contamination to biologically significant, but until we have additional information, we omit this male from the following results. Divergence among the 10 other specimens of $O$. cyanovenata was $0.1 \%$. The reared females from Costa Rica, which were barcoded in another project, are $0.4 \%$ divergent from the South American specimens.

\section{Oenomaus druceus Faynel \& Moser}

http://species-id.net/wiki/Oenomaus_druceus

Distribution, habitat, and remarks. This species was described from one Brazilian (AM) male, which is the only known specimen. As noted, its genitalia are similar to those of $O$. mentirosa, but it has a distinctly different ventral wing pattern.

Female. Unknown. 


\section{Oenomaus floreus (Druce)}

http://species-id.net/wiki/Oenomaus_floreus

Distribution, habitat, and remarks. This species occurs in lowland and lower montane habitats with wet or deciduous forest. It is recorded from eastern Ecuador and Brazil (AM, MT, DF, GO, PR).

New material examined. Ecuador.- 1 0 : Pastaza Province, $45 \mathrm{~km}$ Puyo-Arajuno Rd., 1000 m, 26.IX.1999, Robert C. Busby leg., gen. prep. CF n³42 (RCB). Brazil.2`: GO, $163 \mathrm{~km} \mathrm{W.} \mathrm{Jataí} \mathrm{S.} \mathrm{Rita} \mathrm{Araguaia,} 850$ m, 29.V.1969, S.S. Nicolay, genitalia slide/vial \#4367, prep. S.S. Nicolay (USNM); PR, Highlands, 24.XI.1934, coll. Karl Schmitt, E.I. Huntington, Genitalia 1992: 19ð^ R.K. Robbins (AMNH).

Female. Described by Faynel and Moser (2008).

\section{Oenomaus gaia Faynel}

http://species-id.net/wiki/Oenomaus_gaia

Distribution, habitat, and remarks. This species occurs in wet and dry lowland forest. It has been recorded from Panama, French Guiana, Venezuela, eastern Ecuador, Peru (LO, SM, UC, MD) and Brazil (PA, AM, RO, MT, GO). This species, O. floreus, and maybe $O$. griseus occur in drier forest than other species with an "atena-like" ventral wing pattern.

New material examined. Panama.- 1 ${ }^{\text {}}$ : Los Ríos, C. Z., 15.XII.1964, S.S. Nicolay leg., Genitalia 1992: 73へ R.K. Robbins (USNM ENT 00180046). 2 + : Los Ríos, C. Z., 27.I.1965, S.S. Nicolay, gen. prep. CF n430 (USNM) (Fig. 15); Los Ríos, C. Z., 19.XII.1964, G.B. Small, gen. prep. CF n 431 (USNM). Ecuador.- 1 ${ }^{\wedge}$ : Morona-Santiago $15 \mathrm{~km} \mathrm{~S}$ Gualaquiza, $850 \mathrm{~m}, 3^{\circ} 27.6^{\prime} \mathrm{S}, 7^{\circ} 33.1^{\prime} \mathrm{W}, 27 . I X .2000$, Robert

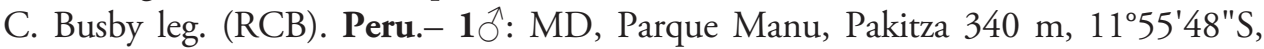
71¹5'18"W, 15.X.1991, Leg. M. Casagrande, Genitalia No. 1992: 38 ${ }^{\Uparrow}$ R.K. Robbins (USNM). Brazil.- 2ô: PA, Obidos, IX.1930, Ex coll. Le Moult, Genitalia No. 1992: $75{ }^{\wedge}$ R.K. Robbins; PA, Santo Antônio do Tauá, Reserva Sonho Azul, $1^{\circ} 15^{\prime} \mathrm{S}, 48^{\circ} 03^{\prime} \mathrm{W}$, 16.VII.2003, P. \& J. Jauffret leg., CF-LYC-072 (CF); RO, 62 km SW Ariquemes, Línea 20, lot 21, 23, 25 (Fazenda Rancho Grande), 11.X.1993, AVZ Brower, gen. prep. CF $\mathrm{n}^{\circ} 411$ (OSAC); GO, Pirenópolis, 820 m, 1549'S, 4859'W, E. Emery leg. (MC 255).

Female. Four males in the USNM were collected on hills on Los Ríos hill (approximately $9^{\circ} 00^{\prime} 32^{\prime \prime N}, 79^{\circ} 35^{\prime} 34^{\prime \prime} \mathrm{W}$ ) and in Cocolí (approximately 8 $58^{\prime} 46^{\prime \prime} \mathrm{N}, 79^{\circ} 35^{\prime} 59^{\prime \prime} \mathrm{W}$ ), Canal Area, Panama. These areas are drier $(<2 \mathrm{~m}$ annual precipitation, Rand and Rand 1982) than the forest in which other Oenomaus with an "atena-like" wing pattern have been found in Panama. Four females from these two localities have the same ventral wing pattern as the males. Since no other males are known from these localities, we associate the sexes and illustrate the adult wing pattern and genitalia of one of these females (Figs 15, 34).

We also associate a female from Brazil, Pará (CF-LYC-072) with a male of O.gaia from French Guiana because they have the same ventral wing pattern and have similar barcode sequences $(0.2 \%)$. 
COI DNA sequence. As noted previously, interspecific variation in the barcode sequences of $O$. ambiguus, O. cortica, O. gaia, O. morroensis is less than $2 \%$, in contrast to interspecific divergences among other species in Oenomaus. For example males of O. gaia (CF-LYC-023) and O. cortica (CF-LYC-052) are $0.8 \%$ divergent. Another male of O. gaia (CF-LYC-024) and O. morroensis (CF-LYC-015) are 1.1\% divergent.

\section{Oenomaus geba (Hewitson)}

http://species-id.net/wiki/Oenomaus_geba

Distribution, habitat, and remarks. This species is a relatively uncommon inhabitant of lower montane forest in southern Brazil, so far known only from the state of Santa Catarina. Previously, it was known only from the male holotype, which lacks locality data.

New material examined. Brazil.- 5 $\hat{\jmath}$ : SC, Highlands near Massaranduba-Blumenau, Collection E.I. Huntington No. 1009 (AMNH, x4); SC, Highlands near Massaranduba-Blumenau, Collection E.I. Huntington No. 1009, genitalia slide/vial \#4705, prep. S.S. Nicolay, Allyn Museum Photo No. 022078-7, 8 VI (AMNH) . 2 \%: SC, Rio Vermelho, São Bento do Sul, 10.III.1973, leg. Rank, gen. prep. CF nº414 (USNM ENT 00180041); SC, Highlands near Massaranduba-Blumenau, Collection E.I. Huntington No. 1009, genitalia slide/vial \#4707, prep. S.S. Nicolay, Allyn Museum Photo No. 022078-9, 10 VI (AMNH).

Female. The female (Figs 12,35) occurs in the same habitat as the male and has the same ventral wing pattern.

\section{Oenomaus griseus Faynel \& Moser}

http://species-id.net/wiki/Oenomaus_griseus

Distribution, habitat, and remarks. This species appears to be endemic to Brazil's central plateau (DF).

Female. Unknown.

\section{Oenomaus isabellae Faynel}

http://species-id.net/wiki/Oenomaus_isabellae

Distribution, habitat, and remarks. This widespread South American species occurs in wet and dry lowland forests. It is recorded from French Guiana, Colombia, eastern Ecuador, Peru, Bolivia, and Brazil (AM, MG).

New material examined. Colombia.- 19: Muzo, 400b. 800 m, coll. Fassl (SMF). Ecuador.- 2 9 : Morona-Santiago, Santiago (Hill North of Town), $3^{\circ} 02.3^{\prime} \mathrm{S}$, $78^{\circ} 00.3^{\prime} \mathrm{W}, 350 \mathrm{~m}, 20 . I X .2010$, Robert C. Busby leg. (RCB); $27 \mathrm{~km}$ Santiago-Puerto Moreno Rd., $2^{\circ} 56.4^{\prime}$ S, $77^{\circ} 49.5^{\prime} \mathrm{W}, 500-550$ m, 17 IX 2005, Robert C. Busby, leg. 
(RCB). Peru.- 1 q: JU, Aldea, 600-700 m, 1054/7455, 23.VIII.2003, J.J. Ramírez (MUSM). Brazil. - 2o : MG, km 500 Belo Horizonte-Brasília, Hwy, 11.IV.1973, C. Callaghan, genitalia slide/vial \#4737, prep. S.S. Nicolay (USNM); AM, Rio Amazonas, Vila Nova (ca. Tonantins, 0252S/6748), 100 m, IX.1993, M. Büche leg. (MUSM).

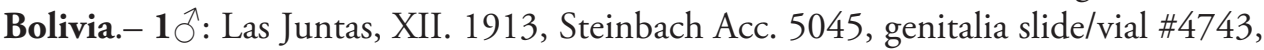
prep. S.S. Nicolay (CMNH).

Female. The distinctive ventral wing pattern of this species allows identification of the female.

COI DNA sequence. Sequences from a Brazilian male (CF-LYC-006) and French Guiana female paratype (CF-LYC-007) diverge 3.0\%.

\section{Oenomaus jauffreti Faynel \& Moser}

http://species-id.net/wiki/Oenomaus_jauffreti

Distribution, habitat, and remarks. This species inhabits wet lowland forest. It is recorded from French Guiana, eastern Ecuador, Peru, Bolivia, and Brazil (PA, MT).

New material examined. Ecuador.- $1{ }^{\lambda}$ : Pastaza Province, $32 \mathrm{~km} \mathrm{~S}$. of Puyo, 20 21.X.1996, 1000 m, Robert C. Busby leg., gen. prep. CF n³46 (RCB). Peru.- 1 $\bigcirc^{\circ}$ : LO, Agua Blanca, 0356/7328, 130 m, 10.XI.2005, J.J. Ramírez (MUSM). 2 ? : JU, vic. Satipo, c. 800 m, Villa Esperanza, c. $11^{\circ} 16^{\prime}$ S, $74^{\circ} 15^{\prime} \mathrm{W}$, V.1983, leg. M. Callegari (USNM) ; LO, Cerros de Contamana, El Indio, 200 m, 10.IX.1986, P. Hocking (MUSM). Bolivia.- $1{ }^{\lambda}$ : Río Songo, 750 m, coll. Fassl, Genitalia No. 2002: 50 R.K. Robbins (SMF).

Intraspecific variation. As noted by Faynel and Moser (2008), O. jauffreti is a variable species, especially ventrally. For example, the VHW basal spot in cell $\mathrm{Sc}_{+} \mathrm{R} 1$ is large and mostly white in French Guiana; is small, black with a white centered pupil in Brazil (MT), and is large, with black and white scales in Ecuador. The only element which seems to be stable is the presence of a white spot on the basal side of VHW cell Rs-M1.

Female. Females were associated with males by their characteristic ventral wing pattern (Faynel and Moser 2008). Six specimens of O. jauffreti have been barcoded (four males and two females), including three male paratypes (CF-LYC-028, CFLYC-029, CF-LYC-030) and one female paratype (CF-LYC-032). The six barcodes show $1.2 \%$ divergence.

\section{Oenomaus magnus Faynel \& Moser}

http://species-id.net/wiki/Oenomaus_magnus

Distribution, habitat, and remarks. This is a poorly understood species that occurs in South American lowland forest. It has been recorded from French Guiana, Peru, Bolivia, and Brazil (AM, MT).

New material examined. French Guiana.- 19 : Approuague - Mapaou, $4^{\circ} 31^{\prime} \mathrm{N}$, $52^{\circ} 13^{\prime} \mathrm{W}, 29$. XII. 2008, S. Fernandez leg. (CF) (Fig. 13). Peru.- 19: SM, Upper 
Huallaga Valley, V-VI 2000, Purch. Thorne 7/01, gen. prep. CF n428 (USNM). Brazil.- 1 ${ }^{\lambda}$ : MT, Diamantino, Alto Rio Arinos, 5.X.1998, E. Furtado leg., gen. prep. CF n446 (MC 254). Bolivia.- 19: "Thecla melleus Drc. 9 , Buenavista 750 m, Bolivia Steinbach., Modt. 22/2 1927 af, qui Steinbach Bolivia, Coll. C.S. Larsen, Faaborg, gen. prep. CF n 449 (MNHN).

Female. We associate females from French Guiana (Figs 13, 36), Peru, and Bolivia with this species. They have the same ventral wing pattern, a similar geographic range, and limited COI DNA sequences are the same.

COI DNA sequence. The sequence of a female from French Guiana (CFLYC-039) is the same as ( $0 \%$ divergence) that of the male paratype from Peru (CFLYC-020). This female is the first record of O. magnus from French Guiana.

\section{Oenomaus melleus (Druce)}

http://species-id.net/wiki/Oenomaus_melleus

Distribution, habitat, and remarks. This species occurs in wet lowland forest. It is recorded from Nicaragua, Costa Rica, French Guiana, Guyana, Venezuela, Colombia, Peru, Bolivia, and Brazil (PA, PE, ES).

New material examined. Costa Rica.- 2 : Heredia, prov. Finca La Selva, $3 \mathrm{~km}$ S. Puerto Viejo, $10^{\circ} 26^{\prime} \mathrm{N}, 84^{\circ} 01^{\prime} \mathrm{W}, 26 . V I I .1992$, leg. H.A. Hespenheide (USNM) ; prov. Heredia, F. La Selva, $3 \mathrm{~km} \mathrm{S.} \mathrm{Pto.} \mathrm{Viejo,} 10^{\circ} 26^{\prime} \mathrm{N}, 84^{\circ} 01^{\prime} \mathrm{W}$, 5.IV.1985, H.A. Hespenheide (USNM). 1\%: Area de Conservación Guanacaste, voucher Janzen \& Hallwachs \#97-SRNP-62841, legs away for DNA, Genitalia 2009: 30 ㅇ R.K. Robbins

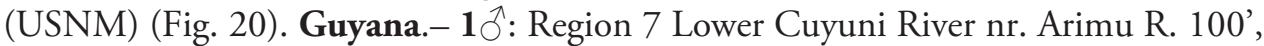

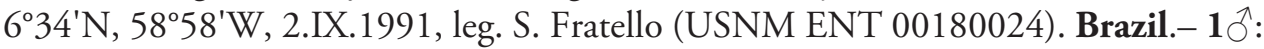
ES, Itaguassú, IX.1971, Paulo César Elias, A.C. Allyn Acc. 1971-38, genitalia slide/vial \#4700, prep. S.S. Nicolay (USNM). 1 \%: PE, Recife, 5.I.1962, leg. Ebert (USNM).

Taxonomy. Faynel $(2007,2008)$ partitioned this species into a Transandean Region (terminology from Brown 1982) nominate subspecies and an Amazonian Region subspecies $O$. melleus guyanensis based on size and color of scales at the base of the VFW. The male genitalia of each taxon were the same. As noted in the next paragraph, the new material examined does not confirm this recognition of two taxa. For example, the Costa Rican specimens resemble the Amazonian ones. For this reason, we synonymize $O$. melleus guyanensis Faynel with $O . m$. melleus (Druce), new synonym.

Intraspecific variation. The wing pattern of $O$. melleus is highly variable. The type from Colombia and two specimens from Nicaragua and Venezuela are relatively large (male FW length $=16.8 \mathrm{~mm}, \mathrm{SD}=1.3, N=3$ ). They have a white spot on the basal part of VHW cell Rs-M1, no reddish scales on the basal part of ventral wing, and a black spot in VHW cell Cu1-Cu2. The specimens from French Guiana, Guyana, Brazil (PA), Venezuela and Peru (UC) are smaller (male FW length $=14.1 \mathrm{~mm}, \mathrm{SD}=0.4$, $N=5$ ). They have a white spot on the basal part of VHW cell Rs-M1, reddish scales on the basal part of ventral wing, and no black spot in VHW cell $\mathrm{Cu} 1-\mathrm{Cu} 2$. The males 
from Costa Rica are also relatively small (male FW length $=14.7 \mathrm{~mm}, \mathrm{SD}=1.6, N=$ 3). They have no white spot on the basal part of VHW cell Rs-M1, no reddish scales on the basal part of ventral wing and a black spot in VHW cell Cu1-Cu2.

Female. Described by Faynel (2008).

Oenomaus morroensis Faynel \& Moser

http://species-id.net/wiki/Oenomaus_morroensis

Distribution, habitat, and remarks. Described by Faynel and Moser (2008) from five males from Brazil (SC, RS), but no other specimens are known. It appears to be a species of lower montane and subtropical forest.

Intraspecific variation. A small white spot on VHW cell $\mathrm{Sc}+\mathrm{R} 1-\mathrm{Rs}$ that is displaced basally (Faynel and Moser 2008) is present in the holotype, but not in the paratypes.

Behavior/biology. Although $O$. morroensis is unrecorded north of Santa Catarina, a reared male from São Paulo (see under O. moseri) could possibly be this species.

Female. Unknown.

COI DNA sequence. One paratype has been barcoded (CF-LYC-015). As already noted, this sequence is $5.0 \%$ divergent from the sympatric and superficially similar O. moseri.

\section{Oenomaus nigra Faynel \& Moser}

http://species-id.net/wiki/Oenomaus_nigra

Distribution, habitat, and remarks. This species occurs in wet lowland forest. It has been recorded from Peru and Brazil (AM). As noted, the genitalia of this species are similar to those of the newly described $O$. myrteana.

New material examined. Peru.- 3 ${ }^{\lambda}$ : LO, Agua Blanca, 0356/7328, $130 \mathrm{~m}$, 17.V.2004, J.J. Ramírez leg. (MUSM, x3). Brazil.- 1 ${ }^{\uparrow}$ : AM, S. Paulo de Olivença, X.1983, Via Kesselring, Genitalia No. 1983: 133ð R.K. Robbins (USNM ENT 00180054).

Female. Unknown.

COI DNA sequence. One male of O. nigra from Peru has been barcoded (CFLYC-148).

Oenomaus ortygnus (Cramer)

http://species-id.net/wiki/Oenomaus_ortygnus

Distribution, habitat, and remarks. This species occurs in many different habitats from sea level up to $1000 \mathrm{~m}$. It is unique in the genus in that it is often found in highly disturbed habitats. It is the most common Oenomaus species in collections and 
has been recorded from the United States, Mexico, Guatemala, Honduras, Nicaragua, Costa Rica, Panama, French Guiana, Surinam, Guyana, Trinidad, Venezuela, Colombia, Ecuador, Peru, and many states throughout Brazil. As noted in the introduction, this species is a well-known pest of commercial Annonaceae.

Intraspecific variation. The blacks spots on ventral wings vary in size and the blue on the dorsal wings vary from light cyan to dark purple. The "Thecla lauta Draudt" phenotype from western Mexico is smaller and duller than individuals from the remainder of its range.

Behavior/biology. Males were territorial on hilltops between 14:00-15:15 hours in Panama (Canal Area, hilltops in Paraíso, 7 males during June and August, 6 vouchers in USNM) and between 14:29 and 15:15 on Serrinha in Brazil (hilltop in Santa Catarina, Villa Nova, 200 m, 3 males in March, vouchers in USNM).

Female. Both sexes are recognized by their ventral wing pattern, which is unique in the genus.

COI DNA sequence. Sequences from a Peruvian male (CF-LYC-147) and a Mexican male (CF-LYC-146) diverge 1.5\%.

\section{Oenomaus poirieri Faynel}

http://species-id.net/wiki/Oenomaus_poirieri

Distribution, habitat, and remarks. This species occurs in wet lowland forest. It has been recorded from French Guiana and Brazil (PA, AM).

New material examined. Brazil.- $1{ }^{\top}$. Santarém, Amazons, A.H. Fassl, 3.IV.1920, gen. prep. CF n 317 (MNHN H-447).

Female. Described by Faynel (2008).

\section{Oenomaus taua Faynel \& Moser}

http://species-id.net/wiki/Oenomaus_taua

Distribution, habitat, and remarks. This species is widespread in wet lowland forest. It is recorded from Guatemala, Panama, French Guiana, eastern Ecuador, Peru, and Brazil (PA, AM, RO). It is one of the more common species in the genus and mating pairs have been collected in Panama, Ecuador, and Brazil.

New material examined. Guatemala.- 1 ${ }^{\lambda}$ : Cayuga, Sept., Schaus \& Barnes coll.,

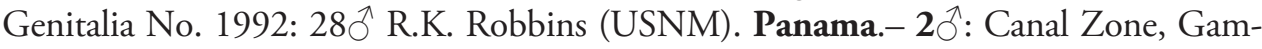
boa, 5.I.1979, Leg. R. Robbins, in copula 15:00, Genitalia No. 1982: 125ð R.K. Robbins (USNM ENT 00180050); Canal Zone, Summit, 17.III.1979, Leg. R. Robbins, in copula 15:00, gen. prep. CF n423 (USNM). 2 : Canal Zone, Gamboa, 5.I.1979, Leg. R. Robbins, in copula 15:00, Genitalia No. 1982: 126 R.K. Robbins (USNM ENT 00180051) (Fig. 18); Canal Zone, Summit, 17.III.1979, Leg. R. Robbins, in copula 15:00, gen. prep. CF n424 (USNM). Ecuador.- 2 ${ }^{\circ}$ : Napo, 14 km Tena-Puyo 
Road, $1^{\circ} 06.7^{\prime} S, 77^{\circ} 46.9^{\prime} \mathrm{W}, 600$ m, X.2010 (Apuya), I. Aldas \& Robert C. Busby leg., gen. prep. CF n 418 (RCB); Napo Province, 14 km S. of Tena, 600 m, 17-18.X.1996 (Apuya), mating pair, Robert C. Busby leg., gen. prep. CF n 345 (RCB). 1 \%: Napo Province, 14 km S. of Tena, 600 m, 17-18.X.1996 (Apuya), mating pair, Robert C. Busby leg., gen. prep. CF n 417 (RCB) (Fig. 19). Brazil.- 1 ${ }^{\top}$ : RO, 160-350 m, vic. Cacaulândia, 10³2'S, 62 48' W, 19.X.1991, in copula, Leg. J. MacDonald, gen. prep. CF n412 (USNM). 1 q: RO, 160-350 m, vic. Cacaulândia, 10³2'S, 6248'W, 19.X.1991, in copula, Leg. J. MacDonald, gen. prep. CF n413 (USNM); PA, Santo Antônio do Tauá, Reserva Sonho Azul, $1^{\circ} 15^{\prime}$ S, $48^{\circ} 03^{\prime} \mathrm{W}, 2 . I I I .2010$, P. \& J. Jauffret leg. (CF).

Intraspecific variation. Females from Brazil and Ecuador (Fig. 19) are uniformly brown on the dorsal wing surface while the female from Panama (Fig. 18) has the basal parts of both wings blue. Their genitalia, however, are uniform. This geographic variability is similar to that in $O$. cyanovenata.

Behavior/ biology. Territorial behavior on a hilltop in Panama (Canal Area, Gamboa, Cerro Pelado) was observed in January and August at 15:00 hours (vouchers in USNM). Two mating pairs were also collected on the same hilltop in January and March at 15:00 hours (vouchers in USNM).

Female. We illustrate adult females that were collected in copula (Figs 18-19) and the genitalia of one (Fig. 37).

COI DNA sequence. A female from Brazil, Pará (CF-LYC-064), which has a wing pattern similar to the females collected in copula, is $3.1 \%$ divergent from a male from Peru (CF-LYC-085).

\section{Discussion}

Taxonomy. A decade ago Oenomaus was a monotypic genus, but it now consists of 28 described species (albeit, it is still unclear if $O$. melleus and $O$. curiosa belong to Oenomaus or Porthecla). Further, if a phylogenetic analysis shows that Porthecla is paraphyletic in terms of Oenomaus, which is possible because Porthecla was distinguished by character states that may be plesiomorphic, then Oenomaus will be one of the most species-rich eumaeine genera with 40 species (Robbins 2004).

There are three biological reasons why the diversity of Oenomaus was not recognized until recently. First, about $3 / 4$ of the species have an indistinguishable, or barely distinguishable, ventral wing pattern that is similar to that of $O$. atena (e.g., Figs 12-19). Among species with this wing pattern, there is a great diversity of male genitalic forms that were first documented by Faynel $(2006,2008)$ and Faynel and Moser (2008). Second, the ventral wing pattern of a few species is different from that of $O$. atena (e.g., Figs 1-7), but similar to that of sympatric species that are now considered to be distantly related. For example, Draudt (1919-1920) in Seitz grouped $O$. ortygnus (the type species of Oenomaus), now placed in the Panthiades Section, with Atlides rustan (Stoll), now placed in the Atlides Section (Robbins 2004). Similarly, he 
placed $O$. atesa in a group with Enos mazurka (Hewitson) in the Brangas Section. Oenomaus myrteana, which is described in this paper, closely resembles Enos myrtea while $O$. mentirosa, also newly described, has a ventral wing pattern that resembles species in Porthecla, Olynthus Hübner, Janthecla Robbins \& Venables, and Atlides Hübner (documented in Faynel et al. 2011). Third, many Oenomaus species are exceedingly rare in collections. Indeed, three species are still known from only one individual each.

DNA barcoding. Thirty-eight Oenomaus males belonging to 19 species have been successfully "barcoded" ( $>200 \mathrm{bp}$ ) (extraction and sequencing methods given in Hajibabaei et al. 2006). For those nine species for which there is more than one barcode (Table 1), intraspecific divergence calculated on the Bold web site (http:// www.boldsystems.org/views/login.php) using the Kimura 2 parameter with sequences aligned by BOLD varied from $0 \%$ to $1.6 \%$. Interspecific divergence (Table 1 ) varied from $0.8 \%$ to $9.7 \%$ (672 comparisons, mean distance: $6.1 \%)$. It was usually greater than $4 \%$ except in the O. cortica species group (O. gaia, O. cortica, O. morroensis), where it was about $1 \%$. Similarity in COI sequences among closely related species is well-established (e.g., Burns et al. 2007).

Male-female associations. Associating males and females in Oenomaus is sometimes very difficult. Only eight of the 28 recognized species previously had the sexes associated. In this paper we associate the sexes of another ten species based on mating pairs collected in copula and on similarity of ventral wing patterns, habitats, geographic distributions, and mitochondrial COI DNA sequences. The DNA "barcodes" have great potential (e.g., Janzen et al 2009), especially if there are large samples from geographically diverse sites.

Biology. Oenomaus ortygnus is a well-known pest of cultivated soursop (also called guanábana, Annona muricata L., Annonaceae) and relatives (e.g., Dampf 1929, Fennah 1937, Ballou 1945, Guagliumi 1965, 1967, Araque 1967, d'Araújo e Silva et al. 1967-1968, Leal 1970, Kendall 1975, Domínguez 1978, Peña et al. 2002, CastañedaVildózola et al. 2011). As noted in the results of this paper, two other Oenomaus species have now been reared, and Annonaceae (Duguetia, Guatteria) is a food plant for each. Although data are yet too scanty to ask why O. ortygnus is the only Oenomaus species that has been recorded as a pest on cultivated Annonaceae, we note that it is also the only Oenomaus species that is regularly found in disturbed habitats.

Most Oenomaus species inhabit relatively undisturbed lowland wet forest, but some species seem to be restricted to other habitats. Oenomaus andi is montane, being found so far only above $1450 \mathrm{~m}$, while $O$. geba is known only from lower montane forest. Oenomaus morroensis occurs so far only in subtropical and lower montane forest. Oenomaus druceus has been found only in scrubby deciduous forest. A number of other Oenomaus species have broader habitat requirements. Some wet lowland species also occur in montane habitats, for which $O$. atesa and $O$. moseri are representative examples. Others, such as $O$. floreus, $O$. gaia, and $O$. isabellae, may inhabit dry deciduous forest. As previously noted, O. ortygnus is the only Oenomaus species that is regularly found in both undisturbed and disturbed habitats. 


\section{Acknowledgments}

We are indebted to Evgeny V. Zakharov (data manager, University of Guelph, Biodiversity Institute of Ontario, Canada) for collaboration in sequencing the mitochondrial COI gene (BOLD project) and Dr D. H. Janzen for allowing us to use his barcode results for Oenomaus from Costa Rica. Accordingly, we thank Stéphane Brûlé (SEAG), Pierre and Jacques Jauffret for hairstreak legs; Jean-Yves Gallard, Serge Fernandez and Thibault Rosant for material from French Guiana.

For allowing us to examine specimens in collections under their care, we are grateful to Dr Jacques Pierre (MNHN), Blanca Huertas (NHM), Dr Gerardo Lamas (MUSM), Dr Olaf H.H. Mielke (DZUP), Dr David Grimaldi and Suzanne Rab Green (AMNH). For giving us access to their personal collections, we thank Pierre Boyer (France), Louis and Yvan Diringer (France), Christian Castelain (France), Alfred Moser (Brazil), Carlos Prieto (Colombia) and Jean-François Le Crom (Colombia).

For comments on the type locality of $O$. moseri, we are grateful to Olaf H.H. Mielke. For allowing us to use his data on the breeding of $O$. moseri, we thank Hipólito Ferreira Paulino Neto (Brazil). For checking Peruvian localities, we thank Gerardo Lamas. For reading and commenting upon the manuscript, we thank John Burns and Carlos Prieto. We also thank the anonymous reviewers for their helpful comments.

Finally, the senior author acknowledges a Smithsonian Institution short term visitor fellowship during summer 2011.

\section{References}

Alcock J, O'Neill KM (1987) Territory preferences and intensity of competition in the grey hairstreak Strymon melinus (Lepidoptera: Lycaenidae) and the tarantula hawk wasp Hemipepsis ustulata (Hymenoptera: Pompilidae). American Midland Naturalist 11: 120-138. http://www. jstor.org/discover/10.2307/2425635?uid=3738016\&uid=2\&uid=4\&sid=21101113843477

Araque R (1967) La guanábana. Serie de Cultivos. Consejo de Bienestar rural (Caracas) 13: $1-16$, figs

Ballou CH (1945) Notas sobre insectos daninos observados en Venezuela 1938-1943. Tercera conferencia interamericana de agricultura (Caracas) 34:1-151.

Brown KS (1982) Historical and ecological factors in the biogeography of aposematic neotropical butterflies. American Zoologist 22: 453-471. http://www.jstor.org/discover/10.2307/ 3882674 ? $u$ id $=3738016 \&$ uid $=2$ \&uid $=4 \&$ sid $=21101113843477$

Burns JM, Janzen DH, Hajibabaei M, Hallwachs W, Hebert PDN (2007) DNA barcodes of closely related (but morphologically and ecologically distinct) species of skipper butterflies (Hesperiidae) can differ by only one to three nucleotides. Journal of the Lepidopterists' Society 61: 138-153. http://entomology.si.edu/staffpages/Burns/JLSx-07Burns.pdf

Castañeda-Vildózola A, Nava-Díaz C, Duarte M, Franco-Mora O, Hernández-Fuentes LM (2011) New Host Plant Records for Oenomaus ortygnus (Cramer) (Lepidoptera: Ly- 
caenidae) in Mexico. Neotropical Entomology 40(4): 512-514. doi: 10.1590/S1519566X2011000400018

Clench HD (1964) A new hairstreak for the United States. Journal of the Lepidopterists' Society 18(3): 189-190.

Comstock JH (1918) The wings of insects. The Comstock Publishing Company, Ithaca, 430 pp. Dampf AEAM (1929) Informe de las actividades de la Oficina Federal para la Defensa Agrícola, durante los meses de enero a marzo de 1929. Boletín mensual. Oficina federal para la Defensa agrícola (Tacubaya, D.F.) 3(1/4): 68-95, 1 pl., 8 figs, 6 tabs.

D’Abrera BL (1995) Butterflies of the Neotropical region. Part VII. Lycaenidae. Black Rock, Hill House, pp. i-xi + 1098-1270.

d'Araújo e Silva AG, Gonçalves CR, Galvão DM, Gonçalves AJL, Gomes J, do Nascimento Silva M, de Simoni L (1967-1968) Quarto catálogo dos insetos que vivem nas plantas do Brasil. Ministério da Agricultura, Rio de Janeiro, Part I, Vol. 1, 422 pp., Vol. 2, 906 pp., Part II, Vol.1, 622 pp., Vol. 2, 265 pp.

Domínguez OE (1978) Insectos perjudiciales del guanábano (Annona muricata L.) en el Estado Zulia, Venezuela. Revista de la Facultad de Agronomía (Maracay) 4(3): 149-163, 9 figs Draudt M (1919-1920) Theclini F. In: Seitz A (Ed) Macrolepidoptera of the World, vol. V, The American Rhopalocera, Stuttgart, Alfred Kernen Verlag, 744-812.

Elias M, Joron M, Willmott K, Silva-Brandão KL, Kaiser V, Arias CF, Gomez Piñerez LM, Uribe S, Brower AVZ, Freitas AVL, Jiggins CD (2009) Out of the Andes: patterns of diversification in clearwing butterflies. Molecular Ecology 18: 1716-1729. doi: 10.1111/j.1365294X.2009.04149.x

Faynel C (2006) Le genre Oenomaus Hübner, 1819, en Guyane française (Lepidoptera, Lycaenidae). Bulletin de la Société Entomologique de France, 111(2): 137-156. http://cat.inist. $\mathrm{fr} /$ ?aModele=afficheN\&cpsidt $=17969795$

Faynel C (2007) Thecla floreus Druce, 1907, et T. melleus Druce, 1907, révision de leur statut (Lepidoptera, Lycaenidae). Bulletin de la Société Entomologique de France, 112(1): 9-15. http://cat.inist.fr/?aModele=afficheN\&cpsidt=18643062

Faynel C (2008) Le genre Oenomaus Hübner, 1819, en Guyane française. 2e partie (Lepidoptera, Lycaenidae). Bulletin de la Société Entomologique de France 113(1): 15-32. http:// cat.inist.fr/?aModele $=$ afficheN\&cpsidt $=20207676$

Faynel C, Moser A (2008) The neotropical genus Oenomaus Hübner with the description of eight new species belonging to the atena group (Lepidoptera, Lycaenidae). Lambillionea, 108(2): Supplément I, 36 pp.

Faynel C, Busby RC, Moser A, Robbins RK (2011) Species level taxonomy of the Neotropical hairstreak genus Porthecla (Lycaenidae: Theclinae: Eumaeini). Ann. Soc. Ent. Fr. 47(1-2): 241-259. http://zoologie.umh.ac.be/asef/contents.asp?action=detailvol\&volID=55

Fennah RG (1937) Lepidopterous pests of the sour-sop in Trinidad. (2) Thecla ortygnus Cramer. Trop. Agric. 14: 244-245 + 2 plates.

Guagliumi P (1965) Contributo all conoscenza dell'entomofuana nociva del Venezuela (coninuazione e fine). Rivista di Agricoltura subtropicale e tropicale 59: 447-472.

Guagliumi P (1967) Insetti e arachnidi delle piante comuni del Venezuela segnalati nel periodo 1938-1963. Relazione e Monografie agrarie subtropicale e tropicale. (N.S.) 86: 391 pp. 
Hajibabaei M, Janzen DH, Burns JM, Hallwachs W, Hebert PDN (2006) DNA barcodes distinguish species of tropical Lepidoptera. Proc Natl Acad Sci USA 103: 968-971. doi: 10.1073/pnas.0510466103

Hebert PDN, Penton EH, Burns JM, Janzen DH, Hallwachs W (2004) Ten species in one: DNA barcoding reveals cryptic species in the neotropical skipper butterfly Astraptes fulgerator. Proceedings of the National Academy of Sciences, USA, 101, 14812-14817. doi: 10.1073/pnas.0406166101

Holdridge LR (1967) Life zone ecology. Tropical Science Center, San Jose, Costa Rica, 206 pp. Janzen DH, Hallwachs W (2012) Dynamic database for an inventory of the macrocaterpillar fauna, and its food plants and parasitoids, of Area de Conservación Guanacaste (ACG), northwestern Costa Rica. http://janzen.sas.upenn.edu [accessed April 2012]

Janzen DH, Hallwachs W, Blandin P, Burns JM, Cadiou J-M, Chacon I, Dapkey T, Deans AR, Epstein ME, Espinoza B, Franclemont JG, Haber WA, Hajibabaei M, Hall JPW, Hebert PDN, Gauld ID, Harvey DJ, Hasumann A, Kitching IJ, Lafontaine D, Landry J-F, Lemaire C, Miller J Y, Miller JS, Miller L, Miller SE, Montero J, Munroe E, Green SR, Ratnasingham S, Rawlins JE, Robbins RK, Rodriguez JJ, Rougerie R, Sharkey MJ, Smith MA, Solis MA, Sullivan JB, Thiaucourt P, Wahl DB, Weller SJ, Whitfield JB, Willmott KR, Wood DM, Woodley NE, Wilson JJ (2009) Integration of DNA barcoding into an ongoing inventory of complex tropical biodiversity. Molecular Ecology Resources 9 (Supplement 1): 1-26. http://entomology.si.edu/StaffPages/Robbins/2009-Janzen-\%20etal_MER-Barcodes.pdf

Kendall RO (1975) Larval foodplants for seven species of hairstreaks (Lycaenidae) from Mexico. Bull. Allyn Mus. 24, 4 pp.

Klots AB (1970) Lepidoptera. In Tuxen SL (Ed) Taxonomist's glossary of genitalia in insects. Munksgaard, Copenhagen, 115-130.

Leal FJ (1970) Notas sobre la guanábana (Annona muricata) en Venezuela. Proceedings of the tropical Region. American Society for horticultural Science 14: 118-121, 2 tabs.

Nicolay SS (1971) A review of the genus Arcas with descriptions of new species (Lycaenidae, Strymonini). Journal of the Lepidopterists' Society 25: 87-108.

Peña JE, Nadel H, Barbosa-Pereira M, Smith D (2002) Pollinators and pests of Annona species, pp. 197-221, 2 figs, 1 tab. In: Peña JE, Sharp JL, Wysoki M (Eds) Tropical fruit pests and pollinators. Biology, economic importance, natural enemies and control. Wallingford, CABI Publishing, 197-221. doi: 10.1079/9780851994345.0197

Prieto CH, Dahners HW (2006) Eumaeini (Lepidoptera: Lycaenidae) del cerro San Antonio: Dinámica de la riqueza y comportamiento de "hilltopping". Revista colombiana de Entomología 32(2): 179-190.

Prieto CH, Dahners HW (2009) Resource utilization and environmental and spatio-temporal overlap of a hilltopping lycaenid butterfly community in the Colombian Andes. Journal of Insect Science 9(16): 1-12, 6 figs, 2 tabs. doi: 10.1673/031.009.1601

Rand AS, Rand WM (1982) Variation in rainfall on Barro Colorado Island. In: Leigh Jr. EG, Rand AS, Windsor DM (Eds) The ecology of a tropical forest, Seasonal rhythms and longterm changes. Smithsonian Institution Press, Washington, DC, 47-59.

Robbins RK (1991) Evolution, comparative morphology, and identification of the eumaeine butterfly genus Rekoa Kaye (Lycaenidae: Theclinae). Smithsonian Contributions to Zool- 
ogy 498: i-iii, 1-64, 116 figs, 17 tabs. http://www.sil.si.edu/SmithsonianContributions/ Zoology/pdf_hi/SCTZ-0498.pdf

Robbins RK (2004) Eumaeini. In: Lamas G (Ed) Checklist: Part 4A. Papilionoidea - Hesperioidea. In: Heppner JB (Ed) Atlas of Neotropical Lepidoptera. Scientific Publishers, Gainesville.

Robbins RK, Duarte M (2004) Descriptions of new butterfly genera. Lycaenidae, Eumaeini. In: Lamas G (Ed) Checklist: Part 4A. Hesperioidea - Papilionoidea. In: Heppner JB (Ed) Atlas of Neotropical Lepidoptera. Volume 5A. Gainesville, Association for Tropical Lepidoptera; Scientific Publishers, 275-282.

Robbins RK, Martins AR, Busby RC, Duarte M (2012) Loss of male secondary sexual structures in allopatry in the Neotropical butterfly genus Arcas (Lycaenidae: Theclinae: Eumaeini). Insect Systematics \& Evolution 43: 35-65. doi: 10.1163/187631212X626195

Scudder SH (1875) Historical sketch of the generic names proposed for butterflies. A contribution to systematic nomenclature. Proceedings of the American Academy of Arts and Sciences, Boston, (2) 10 (2) : 91-293.

Snodgrass RE (1935) Principles of insect morphology. McGraw-Hill Book Co., New York, $667 \mathrm{pp}$. 